\title{
Od heretyckiego mauzoleum do katolickiego sanktuarium Nowe badania kaplicy Matki Bożej przy kolegiacie kórnickiej
}

Streszczenie. Kaplica Matki Boskiej Różańcowej Kórnickiej powstała pierwotnie jako protestanckie mauzoleum, wzniesione w latach 1584-1603 z fundacji Stanisława Górki (zm. 1592), dokończone przez jego siostrzeńca Jana Czarnkowskiego, który przekazał kościół katolikom. Trzy nagrobki wykonali Henryk Horst oraz jego współpracownicy lub naśladowcy. W latach 1735-1737 dawne mauzoleum przekształcono w kaplicę maryjną, w której umieszczono słynący cudami obraz Matki Boskiej. Zachowane wota, fundowane przez szlachtę, burmistrzów, mieszczan i chłopów, pochodzą z czasów od połowy XVII wieku do lat ostatnich. Ołtarz cudownego obrazu wykonali z fundacji mieszczańskiej w latach 1777-1783 Augustyn Szeps, rzeźbiarz z Poznania i miejscowy stolarz Fryderyk Dera. Kaplica od końca XVIII wieku przyjęła też na powrót funkcję nekropoli właścicieli Kórnika - rodu Działyńskich.

Słowa kluczowe: Stanisław Górka, Augustyn Szeps, Teofila z Działyńskich Szołdrska-Potulicka, kaplica kopułowa, Henryk Horst, nagrobki renesansowe, Obraz Matki Boskiej Śnieżnej, wota, ex-wota

\section{Budowa i pierwotny kształt mauzoleum Górków}

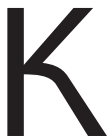

olegiatę kórnicką powołał do życia właściciel miasteczka - biskup poznański Uriel Górka w roku 1495. W połowie XVI stulecia ostatni, sprotestantyzowani Górkowie zagarnęli majątek kapitulny i zniweczyli beneficja. Mimo faktycznej likwidacji kapituły, której nigdy nie przywrócono, nazwa „kolegiata” pokutowała w dokumentach przez kolejne stulecie, aby powrócić 
rykoszetem w wieku XX, tym razem w popularnych publikacjach parafialnych ${ }^{1}$. Obecny proboszcz, ksiądz Grzegorz Zbączyniak, przeprowadzając remonty i renowacje, ożywia sanktuarium Matki Boskiej Różańcowej Kórnickiej (to obecna, oficjalna nazwa), czyni też wstępne zabiegi o prawną restytucję tytułu kolegiaty.

W połowie XVI wieku, wskutek przejścia na inną wiarę, Górkowie utracili prawo pochówku w rodowej kaplicy przy katedrze poznańskiej. Stąd też ostatni z rodu, Stanisław, po śmierci starszego brata Andrzeja, postanowił wystawić w Kórniku familijne mauzoleum i zawarł w tym celu umowę z Henrykiem Horstem, lwowskim rzeźbiarzem pochodzącym z Niderlandów, na wykonanie:

[...] ex marmore et aliis lapidibus in eodem contraktu nominatis et specificatis trium monumentorum in sacello ecclesiae collegiatae Curnicensi[s].

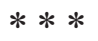

[...] w marmurze i innych kamieniach w tymże kontrakcie wymienionych i wyliczonych trzech nagrobków mających stanąć w kaplicy kościoła kolegiackiego w Kórniku².

Andrzej Górka zmarł 5 stycznia 1583 roku, potwierdzenie kontraktu spisano 21 miesięcy po jego śmierci, 16 września roku 1584, pogrzeb zaś odbył się 22 grudnia tegoż roku, kiedy to ciała obu hrabiów (Andrzeja i zmarłego znacznie wcześniej jego brata Łukasza) złożone zostały do grobu (zur erden bestettiget worden) ${ }^{3}$. Należałoby się więc spodziewać, że kaplica (il. 1-3), przynajmniej w partii krypty, powinna być już wtedy gotowa. Zbudowano ją na rzucie kwadratu, dostawiając od południa do czwartego od zachodu przęsła gotyckiej fary. Nie wiadomo wszakże, czy Horst dostarczył do tego czasu którykolwiek z nagrobnych posągów. Nie wiadomo też, na ile w ogóle wywiązał się z tego zadania przed śmiercią zleceniodawcy, Stanisława Górki, który umarł 23 października 1592. Zaraz potem Jan Czarnkowski, siostrzeniec i spadkobierca Stanisława, przywrócił kolegiatę katolikom, a do 1603 roku ukończył budowę mauzoleum. W każdym razie zapewne w dekadzie pomiędzy 1592 a 1603 rokiem powstały epitafijne tablice Górków, co wynika z analizy ich inskrypcji, wyraźnie, choć w sposób zawoalowany, sceptycznych wobec udziału

1 O ustanowieniu kolegiaty i jej degradacji za czasów ostatnich Górków zob. KowALSKi 2007, s. 47-56; wcześniej: NOWACKi 1964, s. 551, 613-614; WiesioŁowSKi 1997; ostatnio: JUREK 2018, s. 340, 484, przyp. 865 .

2 Zatwierdzenia kontraktu (Approbatiio contractus) pomiędzy Stanisławem Górką a Henrykiem Horstem, APP, A.S. 452, k. 485-486. Tekst odczytał i przełożył na polski Korneliusz Kaczor, zob. KowALSKi 2007, s. 211-214, cyt. s. 211, 213.

3 List uczestnika pogrzebu, Wita von Tobell, do elektora brandenburskiego z 2 stycznia 1585 roku, przeł. Joanna Krauze-Pierz, zob. KowALSKi 2007, s. 215-218, cyt. s. 217. 


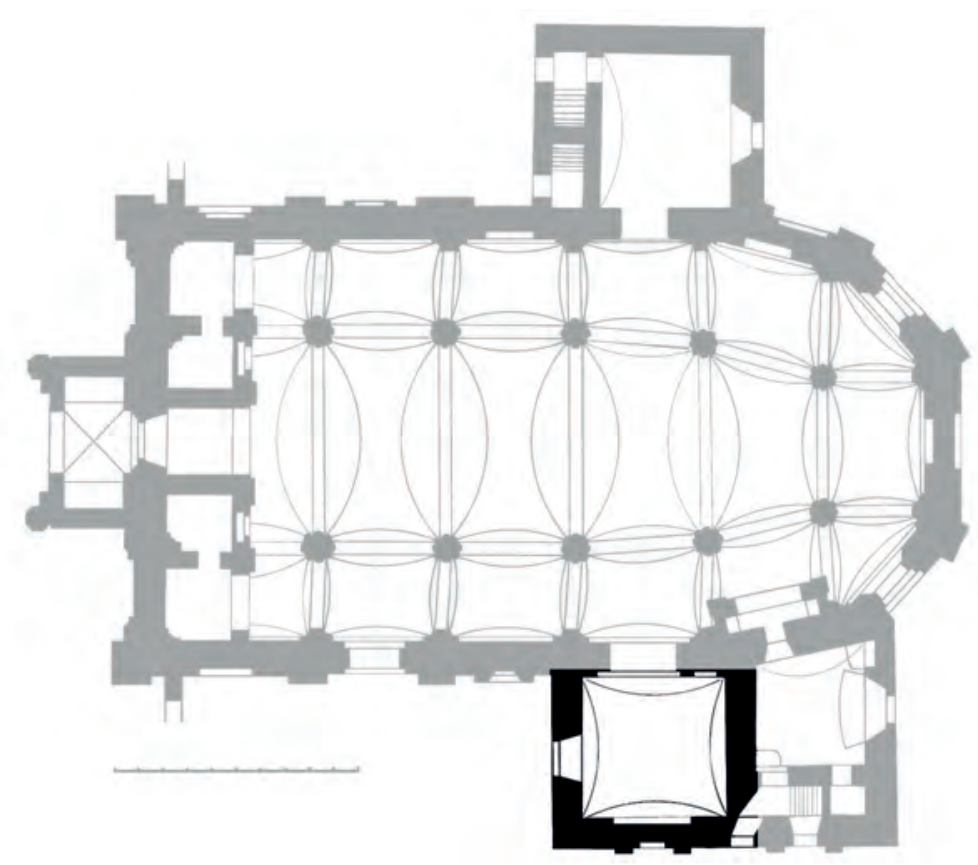

1. Rzut dawnej kolegiaty w Kórniku i dawnego mauzoleum Górków, obecnie kaplicy-sanktuarium Matki Bożej Różańcowej Kórnickiej, oprac. autor

zmarłych w ruchu innowierczym ${ }^{4}$. O ukończeniu (czy jednak ostatecznym?) kaplicy informuje tablica fundacyjna, na której czytamy:

Ioannes de Czarnkow, CastellanVs Medirecensis in Czarnkow, KVrnik et Wielen haeres praesentem Capellam cVm maVsoliis per IllVstrem et MagnificVm DominVm StanislaVm PalatinVm extrVi ac exornari inhoatam sVis sVmptibVs perfecit ac perpetVVm avVncVlis, benemeritis, gratitVdinis monVmentVm reliqVit Anno Domini 1603.

$$
* * *
$$

Jan z Czarnkowa, kasztelan międzyrzecki, dziedzic Czarnkowa, Kórnika i Wielenia, kaplicę tę z grobowcami przez Stanisława Górkę, wojewodę poznańskiego rozpoczętą pod względem budowy i ozdobienia, własnym nakładem dokończył i wujom dobrze zasłużonym pozostawił wieczysty pomnik wdzięczności Roku Pańskiego $1603^{5}$.

\footnotetext{
4 Według napisu nagrobnego Łukasz Górka, przy wszystkich swoich zaletach i sukcesach, został doświadczony nieszczęściem zmiany religii przodków (przeł. ks. Jerzy Kędzierski, cyt. za: KowALSKI 2007, s. 178).

5 Transkrypcja z rozwiązaniem abrewiatur i przekład ks. Jerzy Kędzierski, cyt. za: KowALSKI 2007, s. 180.
} 
TECHNE

T E X N H

SERIA NOWA 136
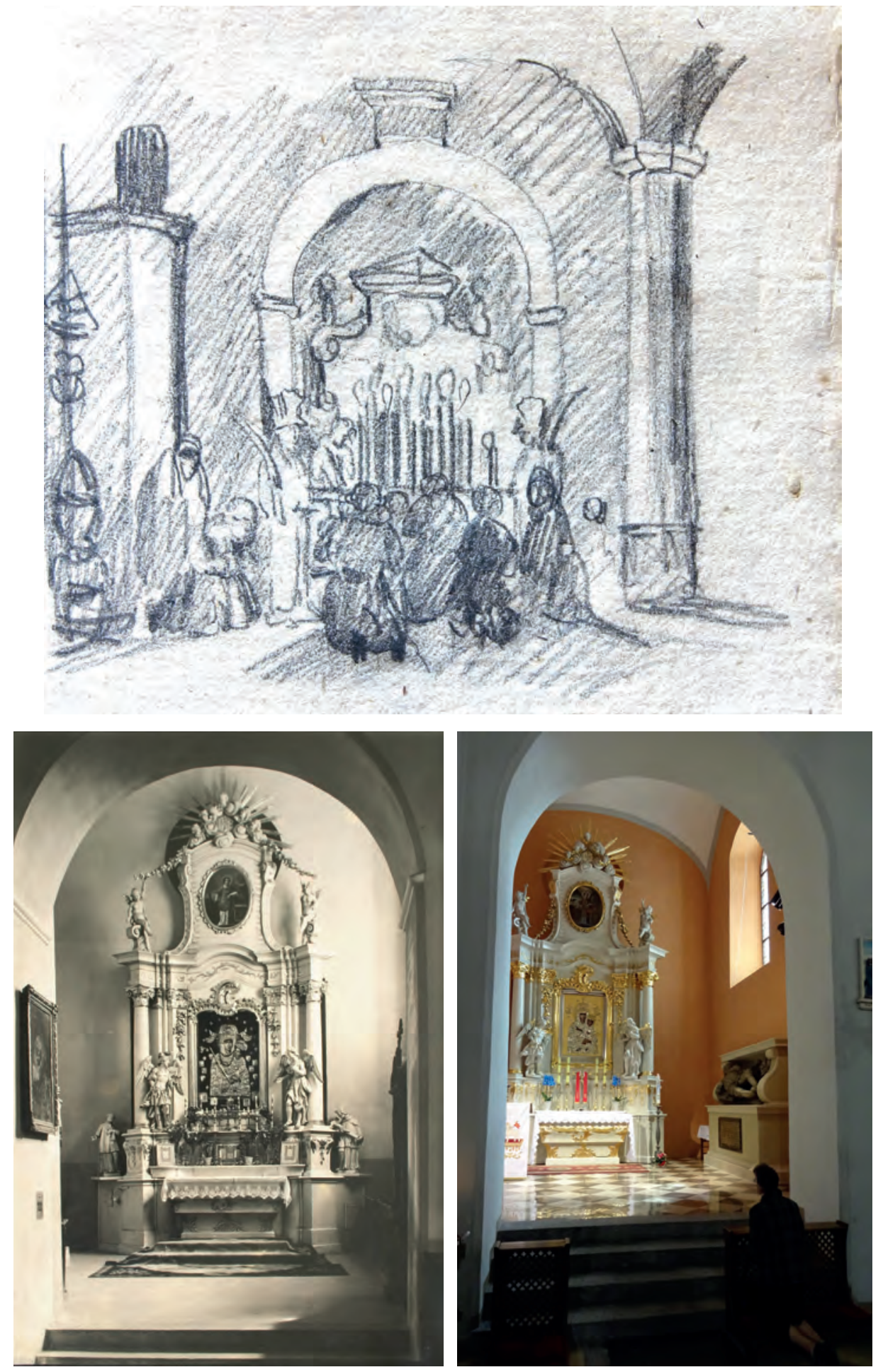

2. Widok na wnętrze kaplicy z nawy kolegiaty: a) szkic Kajetana Wincentego Kielisińskiego, lata 40. XIX wieku, Zbiory Biblioteki Kórnickiej PAN; b) fot. Roman Stefan Ulatowski, 1937, Archiwum Parafii Kórnickiej, repr. za: KoWALSKI 2007, s. 221; c) po ostatniej renowacji, fot. autor, 2019 


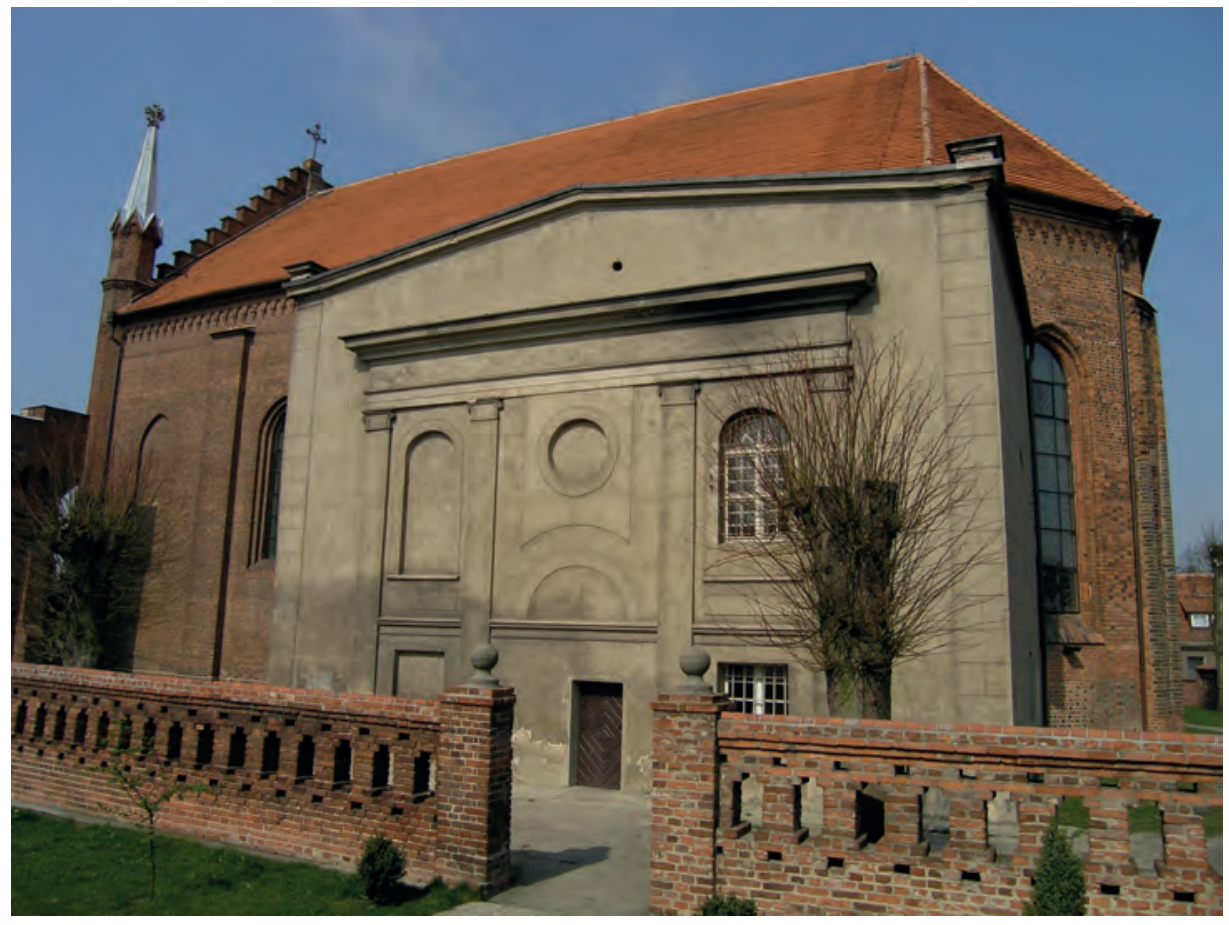

3. Elewacja południowa kaplicy, zakrystii i loży kolatorskiej, fot. Paweł Grabowski, 2005

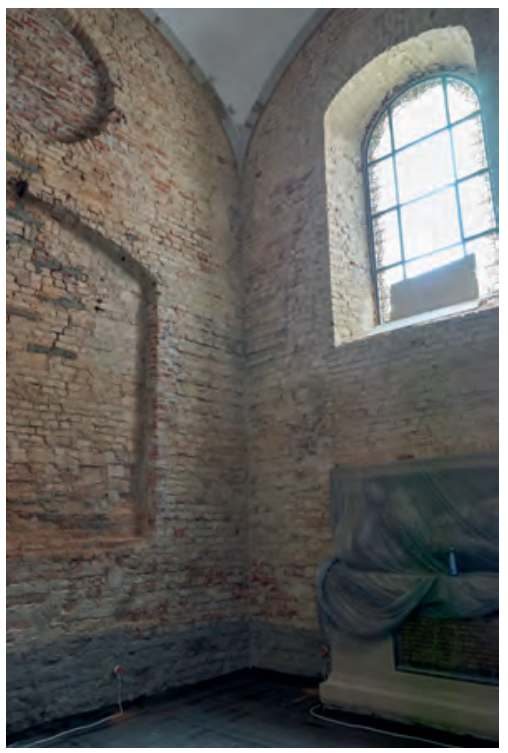

4. Wnętrze kaplicy podczas remontu w 2018 roku - widok ku południowemu zachodowi, fot. Mikołaj Potocki

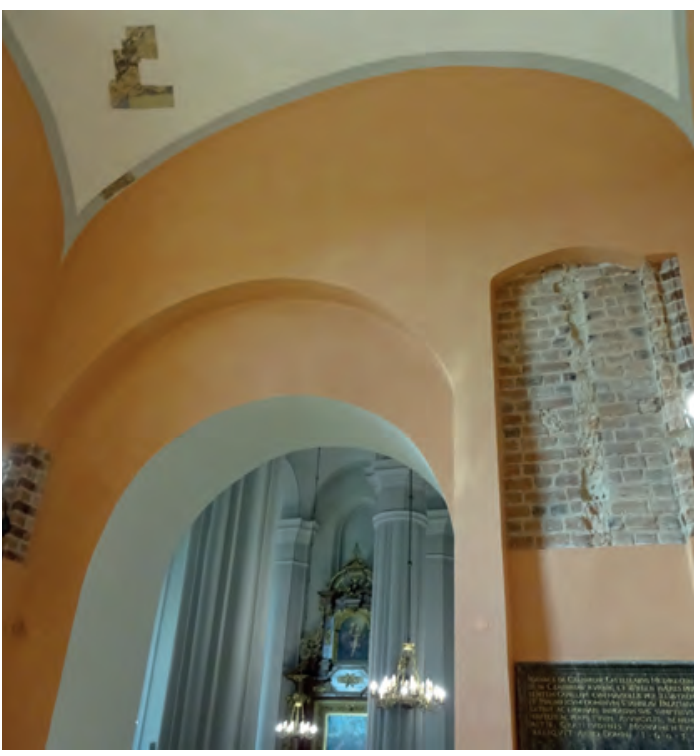

5. Północna, wewnętrzna elewacja kaplicy i fragment czaszy sklepiennej - stan po ostatniej renowacji z 2018 roku. Widoczne „świadki" - fragmenty polichromii na sklepieniu i odsłonięte częściowo gotyckie lizeny z XV wieku, fot. autor, 2019 
Kwestią niejasną pozostaje wciąż autorstwo i chronologia powstawania poszczególnych posągów nagrobnych (il. 6a-c) oraz ich niezachowanych architektonicznych opraw tudzież elementów wyposażenia, a także architektura protestanckiego mauzoleum. Autorzy poświęconych mu studiów ${ }^{6}$, w tym również piszący te słowa ${ }^{7}$ - wypowiadali się rozbieżnie. W ciągu ostatniej dekady doszło do nowych odkryć i ustaleń, które znacznie poszerzają naszą wiedzę o pierwotnym kształcie i wyposażeniu obiektu. Trzy posągi, jak ustalił konserwator Piotr Niemcewicz, odkute zostały z trzech rodzajów kamienia. Są to: oliwkowo-brązowy alabaster z Kąkolników pod Lwowem, czarny wapień Noir de Dinant wydobywany w dolinie Mozy i biały alabaster z Czech. Niegdyś wszystkie te posągi proponowałem, wbrew wcześniejszym badaczom, uznać za dzieło zespołu związanego z Horstem. Tezę tę przyjął i poparł Michał Wardzyński ${ }^{8}$, odmiennego zdania był zaś Mariusz Karpowicz .

$\mathrm{Z}$ czasów protestanckich zachowało się jeszcze w kolegiacie alabastrowe Alegoryczne Ukrzyżowanie (il. 7), niewątpliwie importowane z Niderlandów, skądinąd typowe dla luterańskich mauzoleów, oraz alabastrowy krucyfiks (il. 8), uważany za autorskie dzieło Horsta ${ }^{10}$. Oba te obiekty od wieku XVII znajdowały się w katolickich ołtarzach, nie wiadomo jednak, czy zostały przejęte z mauzoleum ${ }^{11}$, które zasadniczo przez całe XVII stulecie cieszyło się zapewne poszanowaniem, sądząc po zapisie aktów wizytacji z 1695 roku:

In hac ecclesia extat capella in quadro cum mausoliis marmoreis locatum alabastris Illustris Comitis a Gorca alterno fide germanorum fratrum cum fenestris vitreis tribus, quarum una indiget reparatione. Lacunar eiusdem capella rotundum superius foramen apertum, pavimentum nullum imo repletum terra ruinosa. Subter habet formamm lapide clausam, cum tribus lapideis gradibus.

\footnotetext{
6 KęBŁOWSKi 1969; ChrZanOwsKi 1974; SKUratowiCZ 1976; HarasimowiCZ 1986.

KOWALSKI 2007, s. 173-218.

8 Zob. WARDZYŃSKi 2008, s. 118-119.

9 Mariusz Karpowicz odnosił się w gruncie rzeczy do innych, wcześniejszych publikacji (KARPOWICZ 2010, s. 51-59), nie ustosunkowując się do mojej tezy, najwyraźniej nieznanej mu, bo pomieszczonej w książce o regionalnym zasięgu (KOWALSKI 2007, s. 189-200), na co temuż autorowi zwrócił uwagę Adam Soćko (SoćKO 2012).

10 Zob. Krygier 1998; LipińsKa 2001; KRYGIER 2005; WARDZYŃsKi 2008, s. 317-318; wcześniej: ECKHARDTÓWNA 1935.

11 Alabastrowy krucyfiks raczej nie wchodził w skład żadnego z nagrobków, jest na to zbyt duży. Od XVII wieku, po powrocie świątyni do Kościoła katolickiego, zarówno krucyfiks, jak i Alegoryczne Ukrzyżowanie znajdowały się w retabulach stojących w nawach kolegiaty, przy czym krucyfiks od pierwszych dziesięcioleci XVIII wieku do roku 1937 umieszczony był w ołtarzu głównym. Wynika to z analizy aktów wizytacji (począwszy od wizytacji z 1695 roku) i fotografii Romana Stefana Ulatowskiego z 1936 i 1937 roku (na tej pierwszej w zwieńczeniu retabulum widzimy jeszcze krucyfiks alabastrowy, na drugiej zaś snycerski, ten sam, który znajduje się tam również dziś), zob. KOWALSKi 2007, s. 244 i nast., fot. s. 95, 96.
} 
W kościele tym znajduje się kwadratowa [w planie] kaplica z umieszczonymi w niej marmurowymi i alabastrowymi mauzoleami Jaśnie Wielmożnych hrabiów z Górki, rodzonych braci odmiennej wiary; ma trzy oszklone okna, z których jedno wymaga naprawy. Strop tejże kaplicy okrągły, powyżej otworem otwarty; posadzki żadnej nie masz, jedynie zgruzowaną ziemią jest wypełniona. Niżej ma kształt kamiennego zamknięcia z trzema stopniami kamiennymi ${ }^{12}$.

Podczas ostatnich prac renowacyjnych i konserwatorskich, prowadzonych pod nadzorem Urszuli Dąbrowskiej, na sklepieniu kaplicy odkryto ślady malowideł, które można by datować nawet na okres około 1600 roku (il. 5). Niestety, badania ograniczyły się do pojedynczych odkrywek, zaś wczesne datowanie sklepienia wyklucza forma jego żaglastej czaszy, która pojawia się w Wielkopolsce dopiero w drugiej połowie XVII stulecia. Jest ona za to kompatybilna z osiemnastowiecznymi sklepieniami korpusu, co pozwala przyjąć, że sklepienie to założono podczas barokowej przebudowy za czasów Teofili z Działyńskich (o czym dalej). Dlatego możemy domyślać się, że centralny, dziewiętnastowieczny plafon nie ukrywa śladów pierwotnego oculusa (?), odnotowanego przez wizytację z 1695 roku, który odpowiadał zapewne podstawie latarni wieńczącej bądź mającej wieńczyć kaplicę ${ }^{13}$. Forma dawnego sklepienia odpowiadała zapewne rozwiązaniom znanym $\mathrm{z}$ innych wielkopolskich kaplic grobowych końca XVI i pierwszej połowy XVII wieku. Sądząc po śladach przemurowań widocznych w górnych partiach ścian, pierwotna czasza mogła być założona nieco niżej od obecnej (il. 4).

Co do architektonicznej oprawy nagrobków, jeszcze kilkanaście lat temu znane były tylko trzy jej domniemane relikty: alabastrowa czaszka, wtórnie użyta jako kropielnica u wyjścia z zakrystii, fragment belkowania odkryty w 2005 roku w mensie ołtarza św. Anny i konsola z maszkaronem we wnęce ponad arkadą wiodącą do dawnego mauzoleum ${ }^{14}$. Tymczasem roku 2012, podczas remontu piwnic kórnickiego zamku, ujawniła się cała hałda kamiennych elementów: cokołów, gzymsów, konsol z dwiema parami impostów i kapiteli, przy czym jedna para kapiteli jest alabastrowa,

\footnotetext{
12 Archiwum Archidiecezjalne w Poznaniu, AV 18, k. 353 verso, przeł. Jacek Kowalski, cyt. za: KowAlski 2007, s. 195 i przyp. 433. O stosunku katolików do protestanckiego mauzoleum zob. ibidem, s. 244-245, zwłaszcza przypisy 580 i 581.

13 Tak można by odczytywać cytowane powyżej słowa wizytatora (strop tejże kaplicy okrąły, powyżej otworem otwarty), trudno jednak powiedzieć, czy widział on już kaplicę bez latarni czy z latarnią, czy też może latarnia taka nigdy została zbudowana. Ponadto, mimo że na tablicy fundacyjnej czytamy o ukończeniu kaplicy w 1603 roku, to jednak zapis: posadzki żadnej nie masz, jedynie zgruzowaną ziemia jest wypełniona może sugerować, że kaplica nie została wykończona w całości, a „niedoróbek” mogło być przecież więcej.

14 Zob. KowAlski 2007, s. 189 i fot. na s. 181, 182, 191.
} 
TECHNE

\begin{tabular}{l|l} 
T E X N H & 140
\end{tabular}

SERIA NOWA
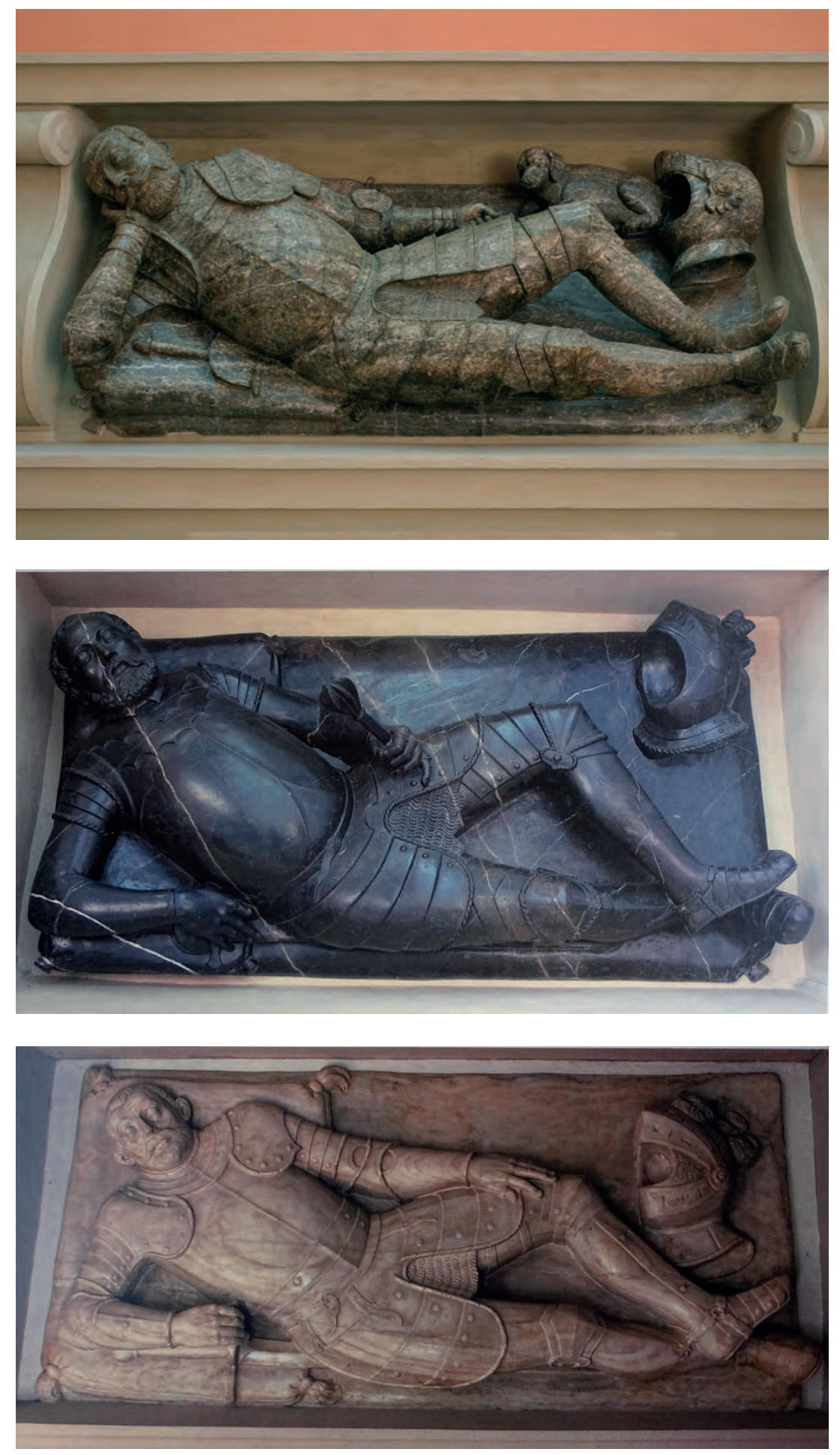

6. Posągi nagrobne trzech braci Górków, przez autora identyfikowane jako wyobrażające: a) Stanisława (powszechnie uważana za figurę Andrzeja); b) Andrzeja (powszechnie uważana za figurę Łukasza); c) Łukasza (powszechnie uważana za figurę Stanisława), fot. Mikołaj Potocki, 2006 
$141 \mid \begin{gathered}\text { TECHNE } \\ \text { TEX N H } \\ \text { SERIA NOWA }\end{gathered}$

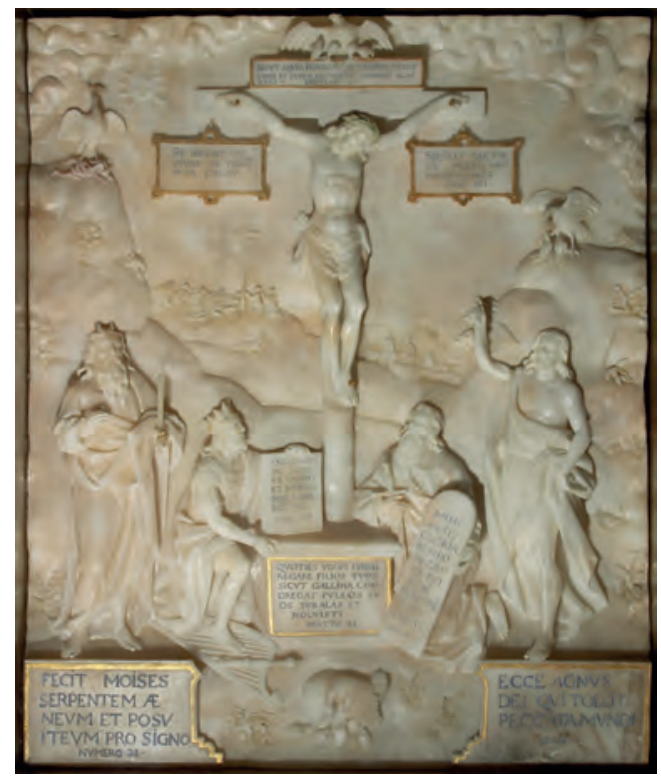

7. Alabastrowe Alegoryczne Ukrzyżowanie, fot. Mikołaj Potocki, 2006

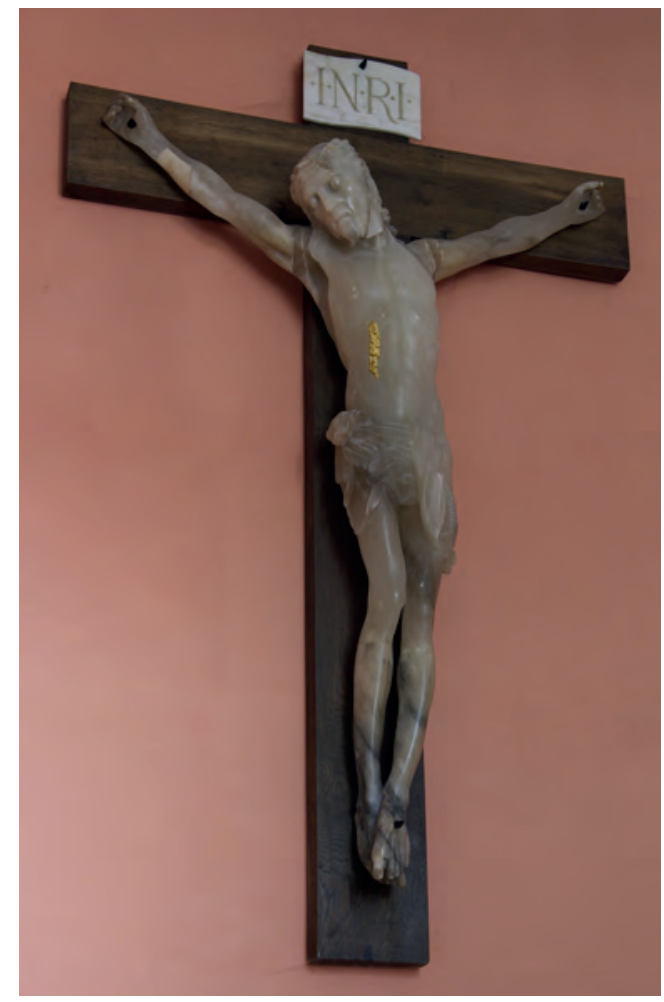

8. Alabastrowy krucyfiks, fot. Mikołaj Potocki, 2006 
druga zaś z piaskowca (il. 9) ${ }^{15}$. Jak ustaliła Justyna Cichońska ${ }^{16}$, elementy z alabastru ${ }^{17}$ przypominają oprawy pomników nagrobnych wykonanych przez Horsta w Brzeżanach pod Lwowem, pozostałe zaś, sporządzone z piaskowca, $w$ tym druga para kapiteli, zgadzają się z formami nagrobka Jana Rydzyńskiego z Ponieca w Wielkopolsce. Oba te dzieła wskazywano już jako należące do dwóch epok - wczesnej i późnej - w działalności Horsta. Justyna Cichońska wsparła jednak zarazem dawną tezę Jana Skuratowicza, wedle której trzy posągi mogły wchodzić w skład dwu nagrobków: jeden z nich byłby piętrowy, podwójny, drugi zaś pojedynczy.

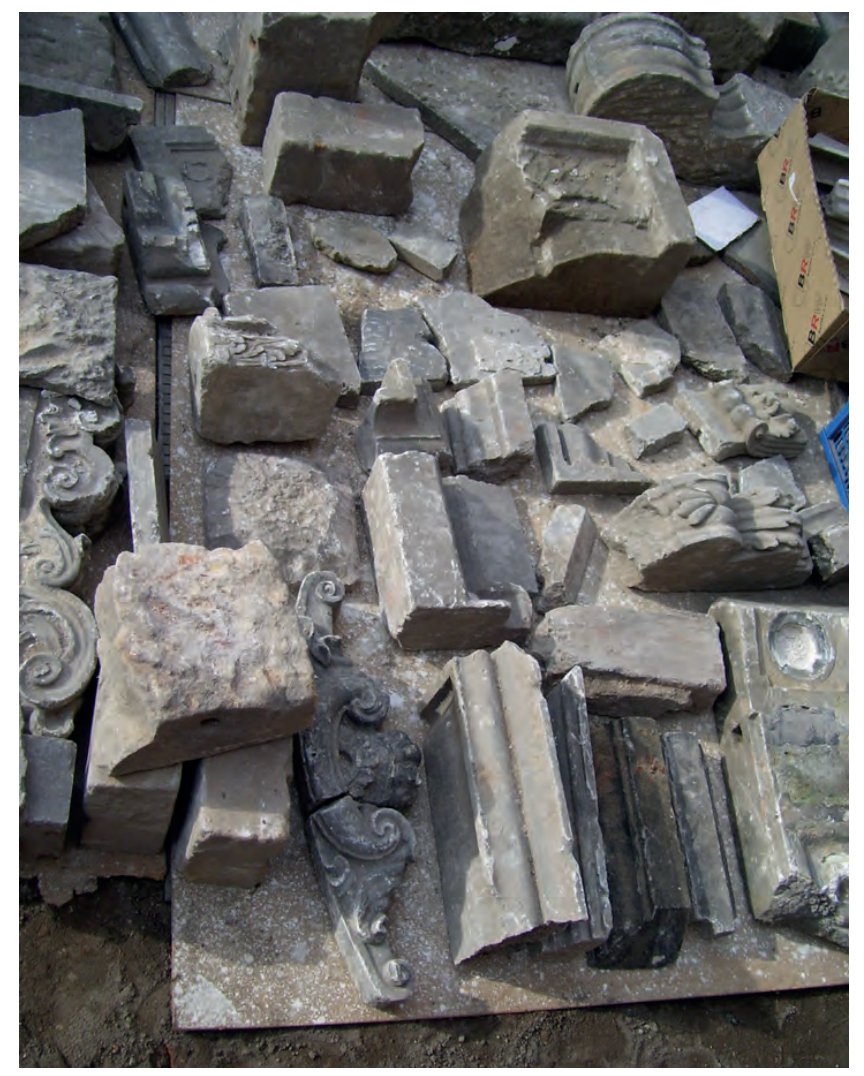

9. Fragmenty architektonicznych struktur pomników nagrobnych, odkryte podczas remontu piwnic zamku $w$ Kórniku, fot. autor, 2012

\footnotetext{
15 Nie ma wprawdzie pewności, czy znalezione detale pochodzą z mauzoleum Górków, trudno jednak wskazać inną przyczynę przechowywania tak licznych alabastrowych elementów w zamku kórnickim - najprościej założyć, że pochodzą z budowli niezbyt oddalonej od rezydencji i związanej z jej właścicielami, a jedyna, jaką można wskazać, jest właśnie tutejsza kolegiata.

16 CiCHOŃsKa 2014.

17 Piotr Niemcewicz wyróżnił trzy rodzaje alabastrów: biały gipsowy, biały z ciemniejszym żyłowaniem oraz pstry - zielono-brązowo-czarny z gęstym żyłowaniem białym. Wszystkie wydobyto z podlwowskich kamieniołomów.
} 
Dodatkowego argumentu dostarczyły wspomniane już niedawne prace remontowe $^{18}$. Po zbiciu tynków $\mathrm{z}$ wewnętrznych elewacji kaplicy naprzeciwko arkady wejściowej ukazała się wielka blenda zamknięta łukiem odcinkowym, który powstał wskutek skucia jej górnej krawędzi - jakby dopasowywano go wtórnie do jakiejś konstrukcji (il. 4). Druga, niższa wnęka znajdowała się w ścianie bocznej. Tym samym objawiły się przynajmniej dwa możliwe miejsca umieszczenia nagrobka piętrowego i pojedynczego, choć trudno powiedzieć, czy na pewno zostały one w ten sposób wykorzystane. Ponadto na wszystkich trzech elewacjach wewnętrznych, prócz wejściowej, ukazały się ślady po elipsoidalnych oculusach, którym w ścianach bocznych niewątpliwie towarzyszyły umieszczone poniżej, półkoliście zamknięte okna, później dopiero przemurowane do obecnych kształtów.

\section{Sanktuarium Matki Bożej Różańcowej Kórnickiej}

Kiedy w roku 1695 katolicki wizytator z uszanowaniem oglądał i opisywał heretyckie mauzoleum, nowy rozdział dziejów kaplicy stał już, by tak rzec, u jej bram, i to dosłownie, bo przy południowo-wschodnim filarze nawy, naprzeciwko arkady prowadzącej do wnętrza. Znajdował się tam wówczas ołtarz z tym właśnie cudownym obrazem Matki Boskiej w typie Śnieżnej (il. 10). Nie wiemy, kiedy sam obraz (czczony w Kórniku do dziś) pojawił się w kolegiacie ani czy od początku był częścią jakiegoś retabulum. W każdym razie prawdopodobny ślad jego obecności w świątyni wskazuje na pierwszą połowę XVII wieku, bowiem już z roku 1650 pochodzi najstarsze zachowane wotum (il. 11), choć oczywiście nie ma pewności, czy łączyło się ono z cudownym obrazem. Niemniej pamiętać trzeba, że popularność obrazów Matki Bożej Śnieżnej datuje się w Polsce od przełomu XVI i XVII wieku, a w niedalekim przecież Poznaniu obraz taki, dotąd powszechnie czczony, namalowano w roku 1631 dla gotyckiej kaplicy Różańcowej przy tamtejszym kościele Dominikanów z fundacji mieszczanina Jakuba Sztyplera ${ }^{19}$. Na przełomie lat 60. i 70. XVII wieku kórnicka Księga Urzędu Burmistrzowskiego odnotowała zapisy testamentowe i wyroki nakazujące przekazać określone sumy na ozdobę Nayświętszej Panny, na świece do Nayświętszej Panny (1667) i na pozłota do ołtarza Nayświętszej Panny $(1672)^{20}$. Ołtarz mógł wówczas przechodzić jakieś przemiany. Zapewne do tego to ołtarza Zofia z Opalińskich Leszczyńska z Bnina, wojewodzina podlaska, ufundowała około roku 1690 niewielki wizerunek św. Wawrzyńca ${ }^{21}$, obecnie znajdujący się

18 Zob. DĄBRowSKa 2019.

19 Zob. KZSP 2002, s. 37. O rozpowszechnieniu kultu obrazu Matki Bożej Śnieżnej w Polsce i jego „kopiach” zob. KorNECKI 1992, ostatnio: BIEŚ/GRZEBIEŃ 2016. O zagadnieniach „rewindykacji” dzieł sztuki katolickiej przez innowierców i vice versa zob. JURKOWLANIEC 2008.

20 Księga Urzędu Burmistrzowskiego, odpowiednio fol. 16 verso, fol. 44 verso, fol. 84 verso.

21 Fundatorkę obrazu przekonująco zidentyfikował Marek Krygier, zob. KRYGIER 1999. 


\section{TECHNE \\ T E X N H \\ SERIA NOWA

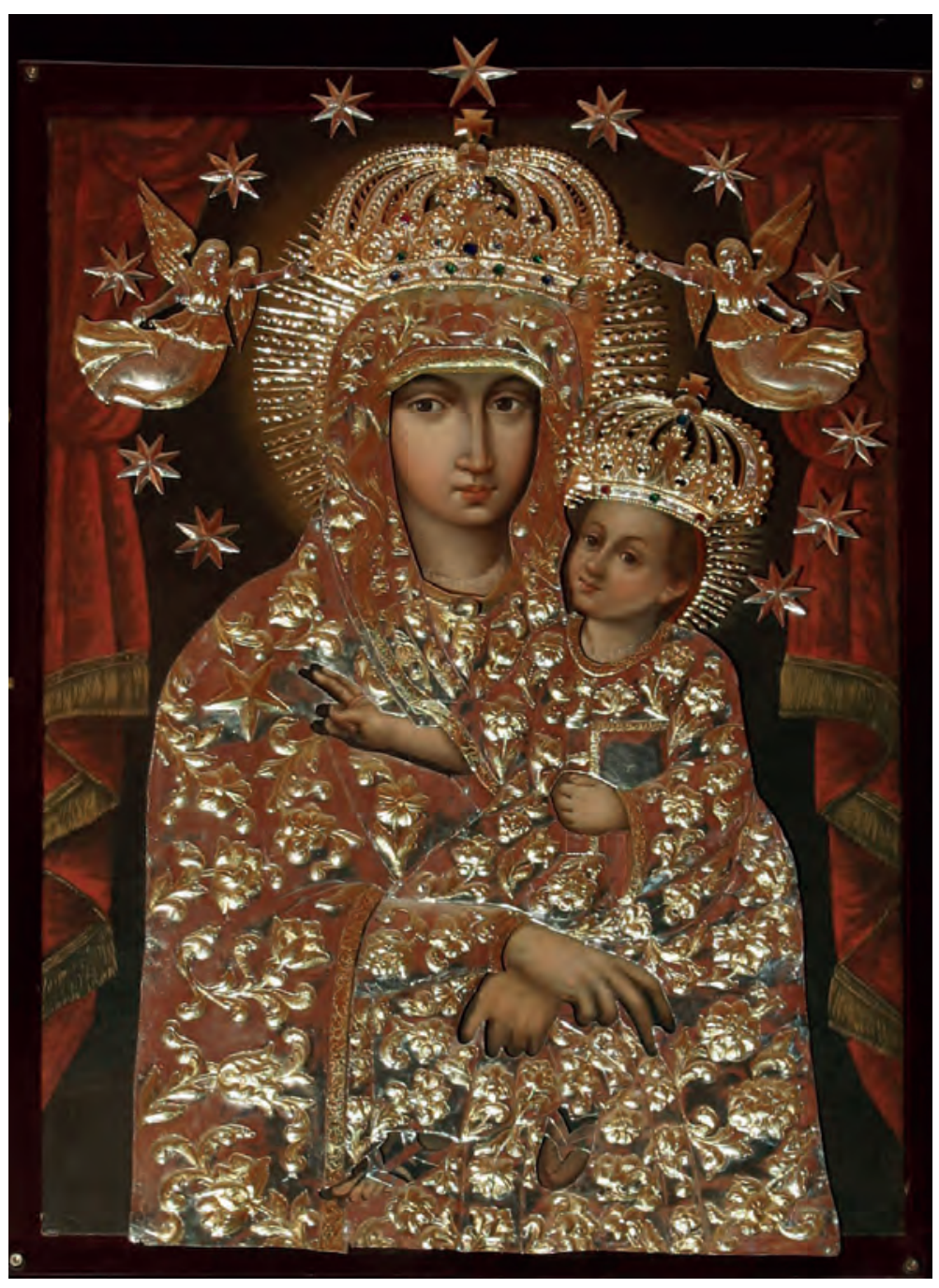

10. Obraz Matki Boskiej Kórnickiej w srebrnej sukience fundacji Działyńskich, fot. Mikołaj Potocki, 2006

w górnej kondygnacji późniejszego, rokokowego ołtarza w kaplicy. W końcu XVII wieku sanktuarium miało już lokalną sławę, którą głoszono z okolicznych ambon ${ }^{22}$, oraz bractwo różańcowe. Powstanie takowego łączyło się zwykle z fundacją ołtarza i osobnego wizerunku Matki Bożej. Tak nakazywały odgórnie narzucane statutowe reguły brackie. Wszystko wskazuje na to, że w Kórniku rzecz miała się na odwrót: ołtarz i wizerunek (zapewne od dawna słynący cudami) istniały wcześniej, a bractwo

22 Dziękuję za tę informację pani Wandzie Karkucińskiej, która podczas kwerendy wykonywanej w innym celu natknęła się w zbiorach Biblioteki Kórnickiej na drukowane kazanie z końca XVII wieku, wspominające Matkę Bożą cudowną w kórnickim obrazie. Niestety, wzmianki tej nie umieściła w swoich notatkach i dlatego informacja pozostaje wprawdzie pewna, lecz niepełna. 

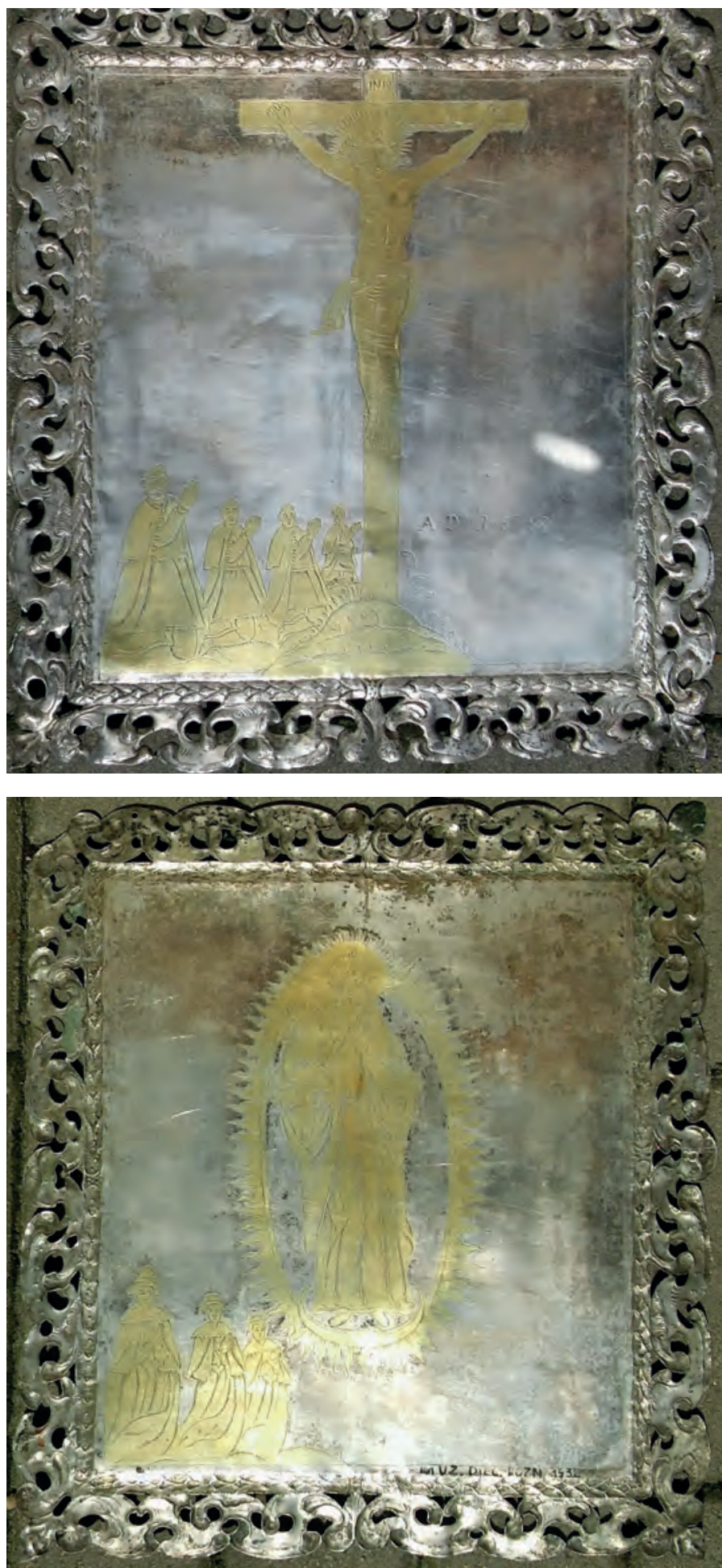

11. Pochodząca z kolegiaty kórnickiej blacha wotywna nieznanej rodziny szlacheckiej z 1650 roku fot. ze zbiorów Muzeum Archidiecezjalnego w Poznaniu 
zawiązało się przy nich wskutek już istniejącego kultu. Stało się to w zwrotnym momencie dziejów miasta, które Zygmunt Działyński nabył drogą kupna od Karola Grudzińskiego. Zygmunt Działyński był człowiekiem wybitnie pobożnym, pielgrzymem do Jerozolimy, dobrodziejem sławnej Kalwarii Pakoskiej. Wspomniana transakcja przypadła na rok 1676, ale nowy właściciel wszedł w faktyczne posiadanie dóbr kórnickich dopiero rok później, przejmując miasto z rąk wdowy po Karolu Grudzińskim, Marianny. I oto właśnie w tym przejściowym roku 1677 z inicjatywy pani Grudzińskiej zawiązać się miało bractwo różańcowe. Mówi o tym księga bracka oraz wspomniane już akta wizytacji świątyni z roku 1695. Można sądzić, że zarówno poprzedni, jak i nowi właściciele, a także najważniejsi obywatele parafii - z miasta i pobliskiej wsi Pierzchno, gdzie znajdował się kościół filialny - postanowili poczynić z tej okazji wyjątkowe fundacje, czyli okazać specjalną cześć dla Matki Bożej i zadbać o uświetnienie istniejących już ołtarza i obrazu. Najpoważniejszą fundacją jest srebrna sukienka Matki Bożej ofiarowana już przez nowych kolatorów (il. 10). Wskazuje na to zakamuflowana sygnatura w postaci godła herbu Działyńskich - Ogończyk - w które układają się rzemyki sandałka na prawej nóżce Dzieciątka. Cała sukienka ozdobiona została charakterystycznym motywem bujnych kwiatów, stosowanym przez złotników w siódmym i ósmym dziesięcioleciu XVII wieku. Fundatorem (jedynym?) mógł zatem być zarówno Zygmunt Działyński (zm. 1685), jak i jego syn Paweł (zm. 1694).

W początku stulecia XVIII kolegiata kórnicka, zagrożona zawaleniem sklepień, została zamknięta; nabożeństwa, a wraz z nimi także i ołtarze przeniesiono do drewnianego kościoła św. Ducha. Dopiero 30 lat później, w latach 1735-1737, za czasów proboszcza Szymona Niżewskiego oświecona dziedziczka, Teofila z Działyńskich ${ }^{23}$, sfinansowała kapitalny remont kościoła. Niewątpliwie na jej polecenie rozebrano architektoniczne struktury nagrobków. Dwa posągi nagrobne wmurowano wtedy w ściany prezbiterium po obu stronach ołtarza głównego, trzeci, najpiękniejszy, pozostawiono w kaplicy, nie wiemy jednak, czy w pierwotnej oprawie ${ }^{24}$. Bodaj teraz dopiero położono tutaj ceglaną posadzkę, ostatnio odsłoniętą, a przede wszystkim wprowadzono ołtarz z cudownym obrazem Matki Boskiej Różańcowej. Stało się to zapewne w 1739 roku; taką datę nosi znaleziony w obecnej mensie portatyl z relikwiami świętych Prudencji i Witalisa ${ }^{25}$. Pięć lat później, w roku 1744, proboszcz wyasygnował środki na dachówkę, którą pokryto dach kaplicy ${ }^{26}$.

\footnotetext{
23 KARKUCiŃSKA 2007, s. 108-109, 115.

24 ŁUKASZEWICZ 1858-1863, t. 1, s. 337-338.

25 Zob. KRYGIER 1999.

26 Archiwum Parafii Kórnik, teczka Akta Kościoła parafialnego Kórnickiego tyczace się sreber kościelnych No 42, Pfarramt Kurnik 59, 41, nr 9144, k. 5.
} 
Obecny ołtarz powstał jednak dopiero w latach 1777-1783 z fundacji kórnickich mieszczan, Celestyny i Zacheusza Robińskich, którzy ofiarowali na ten cel po 100 złotych polskich; dołożył się także pisarz prowentowy Józef Matelski i nadworny krawiec Teofili z Działyńskich - Józef Pudelewicz. Rokokowe retabulum wykonali: znany poznański rzeźbiarz Augustyn Szeps oraz miejscowy stolarz kórnicki - Fryderyk Dera. Ołtarz został wówczas odmalowany i pozłocony, kaplicę zaś wybielono, po czym malarz Fryderyk Szeyn, obywatel Poznania, wykonał na sklepieniu postaci czterech doktorów Pisma Ś $w .{ }^{27}$. W retabulum, stojącym do dziś w kaplicy, zachowało się kilka elementów różnych wcześniejszych nastaw, przede wszystkim umieszczony w drugiej kondygnacji siedemnastowieczny obraz św. Wawrzyńca. Współczesne rokokowemu retabulum są natomiast trzy srebrne serca (wota lub ex-wota?) sygnowane przez Józefa Götza z Hubertsburga, złotnika czynnego w Poznaniu w latach $1777-1785^{28}$.

W ten sposób kolegiata kórnicka zyskała swoją na długo jedyną kaplicę i zarazem sanktuarium Matki Boskiej, które skądinąd nadal służyło jako nekropolia kolejnych kolatorów kościoła. W krypcie pod kaplicą spoczęła fundatorka sanktuarium, Teofila z Działyńskich, a później złożono tam ciała przedstawicieli ostatnich pokoleń rodu Działyńskich. Syn Teofili już po śmierci matki zlecił budowę nowej zakrystii z lożą kolatorską, której dwa przeźrocza otwierały się odpowiednio do prezbiterium

27 Archiwum Państwowe w Poznaniu, Akta miasta Kórnika 1/9, s. 144-145, 147, cyt. za: KąSINOWSKA 2019, s. 90, zob. też przyp. 365. Autorka ustosunkowała się do mojej monografii kolegiaty kórnickiej z 2007 roku (KowALSKI 2007), podnosząc m.in. brak badań architektonicznych, które upoważniałyby do szczegółowego ustalenia dziejów budowy kościoła w średniowieczu (KĄSINOWSKA 2019, s. 22-23, przyp. 71). Zwróciła też uwagę na fakt istnienia rachunków związanych z pracami przy barokowo-klasycystycznej i romantycznej przebudowie, które zawierają nazwiska majstrów budowlanych (ibidem, s. 98, przyp. 399; s. 122, n. 496). Źródła te były mi niegdyś nieznane. Autorka nie zgadza się z tezą, jakoby gotyckie sklepienia rozebrano podczas prac prowadzonych w pierwszej połowie XVIII wieku: nieliczne wzmianki w źródłach z lat 1722 i 1735-1737 o pracach przy kościele, brak zawieranych $z$ wykonawcami kontraktów i innych źródet, a także brak profesjonalnych badań architektonicznych kórnickiego kościoła nie upoważniaja do sugerowania, że za czasów Stefana i Teofili Szołdrskich wzniesiono gotycki dach i sklepienia, zastępując je nowymi. Raczej istniejące pokrycie zreperowano, a wokół przykościelnego cmentarza postawiono nowe ogrodzenie (ibidem, s. 90, przyp. 363). Mimo wszystko podtrzymuję moją tezę o powstaniu sklepień świątyni w XVIII wieku, a to przez wzgląd na charakter impostowych kapiteli i przyściennych filarów, które zgadzają się z takim właśnie datowaniem, znacznie mniej natomiast odpowiadałyby etapowi romantycznej odbudowy po 1837 roku. Pokrewieństwo formy sklepienia kaplicy i sklepień założonych w nawach świątyni również każą uważać je za wzniesione równolegle lub w nieodległych od siebie kampaniach budowlanych. Zaznaczam, że w ciągu ostatnich kilkunastu miesięcy przeprowadzano w kościele kolejne badania architektoniczne, których szczegółowe wyniki nie są mi jeszcze znane.

28 O Józefie Götzu z Hubertsburga zob. DolCzewSKi 2000, s. 15, nr 86. Serca te nie noszą ani daty, ani nazwiska, ani inicjałów darczyńcy. Podejrzewam, że ów zespół liczył pierwotnie cztery serca przytwierdzone symetrycznie wokół obrazu, może ufundowane właśnie z okazji powstania nowego, czyli obecnego retabulum. Z lat późniejszych, przede wszystkim z XIX wie$\mathrm{ku}$ pochodzi około 30 wotów w postaci mniejszych lub większych srebrnych serc, przeważnie pozbawionych inskrypcji. 
i do wnętrza sanktuarium, przy czym to drugie miało ukośnie opracowane ościeża kierujące spojrzenie ku ołtarzowi ${ }^{29}$. Połączono wówczas cały zespół kaplicy, zakrystii i loży w jedną bryłę o wspólnej elewacji, która skutecznie maskuje jej wewnętrzną niejednorodność.

Od tego czasu wnętrze kaplicy zmieniało się już stosunkowo nieznacznie, jeśli nie liczyć przemieszczeń drewnianych figur ołtarzowych i obrazów, znikania i ponownego pojawiania się wotów. Kaplica - podobnie jak i dziś - służyła za miejsce czasowych aranżacji szopki czy grobu Pańskiego, co uwiecznił Kajetan Wincenty Kielisiński na szkicu z lat 40. XIX wieku (il. 2c). Po pożarze kościoła w roku 1837 właściciel dóbr kórnickich, przebywający wówczas na emigracji hrabia Tytus Działyński, sfinansował remont i budowę nowej, imponującej neogotyckiej fasady według projektu Franciszka Marii Lanciego. Projekt ten był bez wątpienia inspirowany zarówno przez samego Tytusa, jak i przez jego małżonkę Celestynę z Zamoyskich. We wnękach partii cokołowej miały znaleźć się - niewątpliwie na zasadzie prezentacji chwalebnej przeszłości kościoła, miasta i narodu - wyprowadzone z wnętrza dwie nagrobne figury rycerzy - Górków. Ostatecznie jednak przeniesiono tylko jednego rycerza, tego, który wcześniej pozostał w kaplicy, odtąd zaś spać miał na fasadzie, jak napisano wówczas w „Przyjacielu Ludu”: snem kamiennym po trudach tego $\dot{z} y w_{\text {wota }}{ }^{30}$. U końca XIX wieku jego stan wywołał urzędową interwencję pruskiego konserwatora zabytków, który wystosował do kurii wezwanie, aby figurę umieścić na powrót w kaplicy Matki Boskiej Kórnickiej. Kuria przekazała sprawę proboszczowi, księdzu Bronisławowi Rybickiemu. Jedyną znaną mi reakcją kapłana był odręczny dopisek na marginesie kurialnego monitu: heretyk wyniesiony z kościoła ${ }^{31}$. Przez następne 100 lat, czyli prawie do końca XX stulecia, kolejni proboszczowie ${ }^{32}$ i sekundująca im rada parafialna ${ }^{33}$ podobnie zbywali kolejne konserwatorskie wezwania. A przecież ów heretyk nie został wcale „wyniesiony” za karę, przeciwnie - trafił na fasadę jako świadectwo świetlanej przeszłości Kórnika i Rzeczypospolitej. I mimo że ostatnio powrócił do kaplicy Matki Boskiej, parafianie nadal mówią, że wyrzucono go z kościoła za karę - na zewnątrz, tam, gdzie będzie płacz i zgrzytanie zębów. Cóż, vox populi - vox Dei.

\footnotetext{
29 Oba przeźrocza zostały w ciągu ostatnich dziesięcioleci zamurowane.

30 Kościół 1841, s. 90.

31 Dopisek ks. proboszcza Bronisława Rybickiego na liście z konsystorza arcybiskupiego z 13 listopada 1898, Archiwum Parafii Kórnik, teczka Akta dot. pomnika Andrzeja Górki. Kath. Pfarramt Kurnik 59, 41, nr 9122, cyt. za: KoWALSKI 2007, s. 209 (w przyp. 481 mylnie wpisana data 1989 zamiast 1898).

32 Ibidem, listy konsystorza z 13 września, 28 października, 18 listopada, 29 listopada 1898 roku oraz 21 czerwca i 3 listopada 1976 roku.

33 Kosman 1978, s. 42.
} 


\section{Nowożytne wota kórnickiego sanktuarium}

Najstarsze znane i zachowane wotum (il. 11), przypomniane dopiero niedawno, pozostaje od roku 1973 w zbiorach Muzeum Archidiecezjalnego jako depozyt parafii kórnickiej ${ }^{34}$. Jego opis rozpoznajemy bez trudu w aktach wizytacji z roku 1737, przy czym, co ciekawe, ta cenna blacha nie znajdowała się w bezpośredniej bliskości obrazu (może z powodu trwającej wówczas renowacji?):

Tabula argentea notabilis cum effigie Crucifixi D[omi]ni, ex una parte, ex altera vero $\mathrm{B}$ [eatae] $\mathrm{M}$ [ariae] V[irginis] inter radios, deaurata ex utraq[ue] parte, continens ex una annum expressum 1650. quod supponitur fuisse loco Epitaphii Pro[vi]sorum Głoskowskich.

Godna uwagi srebrna tablica $\mathrm{z}$ wyobrażeniem Ukrzyżowanego Pana $\mathrm{z}$ jednej, a Najświętszej Marii Panny w promieniach z drugiej strony; z obu stron złocona, ma po jednej stronie wypisany rok 1650, położona w miejscu epitafium prowizorów Głoskowskich ${ }^{35}$.

Nic dziwnego, że przedmiot ten wzbudził zainteresowanie wizytatora; srebrna blacha jest bowiem stosunkowo duża, znacznie większa od wszystkich pozostałych $(36 \times 33 \mathrm{~cm})$, a pod względem formy dość wyjątkowa, bo dwustronnie rytowana i następnie częściowo złocona, o półplastycznej ramie z ażurowego ornamentu. $\mathrm{Na}$ awersie szlachcic z trzema synami klęczy pod krucyfiksem, rewers ukazuje klęczącą szlachciankę w towarzystwie trzech córek pod wyobrażeniem stojącej Marii z Dzieciątkiem w płomienistej mandorli, z księżycem pod stopami. Na awersie zapisano datę: A.D. 1.6.5.0. W przypadku dość rzadkich wotów dwustronnych pojawia się zawsze pytanie o sposób ich pierwotnej ekspozycji. Przytwierdzenie blachy bezpośrednio do retabulum czy obrazu skazywało rewers - w tym przypadku ukazujący

\footnotetext{
34 Muzeum Archidiecezjalne w Poznaniu, nr inw. MAdP 1939, zob. DzIUbKowa 2004, s. 205, nr kat. 320. W powyższej nocie katalogowej nie wspomniano o proweniencji wotum, które zostało wpisane do inwentarza Muzeum Archidiecezjalnego w Poznaniu dopiero w 1973 roku jako depozyt parafii kórnickiej. Dlatego też, pisząc monografię artystyczną tamtejszej kolegiaty (KOWALSKI 2007), nie wiedziałem, że opisywane przeze mnie wotum, skądinąd wymienione w aktach wizytacji z 1737 roku (zob. następny przypis), jeszcze istnieje. Za tę informację dziękuję serdecznie Michałowi Błaszczyńskiemu. Warto w tym miejscu zauważyć, że nie potwierdziła się opinia Zofii Białłowicz-Krygierowej, która uważała niegdyś, że pośród zachowanych wotów znajdują się obiekty z czasów bezpośrednio po 1604 roku, zob. KZSP 1961, s. 19.

35 Archiwum Archidiecezjalne w Poznaniu, sygn. AV 23, k. 13 recto, spisał i przeł. Jacek Kowalski (tłumaczenie poprawione w stosunku do pierwotnie opublikowanego w: KoWALSKI 2007, s. 61).
} 
Matkę Boską i żeńskie reprezentantki rodu - na trwałe ukrycie. Na podstawie aktów wizytacji możemy przynajmniej tyle powiedzieć, że wotum podczas ich spisywania było zawieszone bez związku z obrazem, zapewne na ścianie świątyni (jako że niedaleko epitafium), i że wizytator nie miał problemów z obejrzeniem go z obu stron. Wizytacja ta miała jednak miejsce po okresie przenoszenia cudownego obrazu do kościoła św. Ducha i z powrotem, a wota mogły przemieszczać się niezależnie.

Ta sama wizytacja z 1737 roku odnotowała srebrną sukienkę obrazu Matki Bożej, koronę, dwie blachy w kształcie aniołów, dwanaście gwiazd, berło, łańcuszki oraz Tabellae votivae duae et manus argente, czyli zaledwie dwie tabliczki wotywne i ramię ze srebra ${ }^{36}$. Wszystkie te przedmioty rozpoznajemy pośród pozostałych, zachowanych w istniejącym zbiorze wotów; obecnie wszakże towarzyszą im inne liczne siedemnasto- i osiemnastowieczne, których wizytator nie zauważył. Czyżby na czas przeniesienia nabożeństw do kościoła św. Ducha - czyli na ponad 30 lat! - umieszczono je gdzie indziej? Czy też pochodziły z innych ołtarzy i dopiero później zostały przeniesione do ołtarza Matki Boskiej? To drugie rozwiązanie nie jest zbyt prawdopodobne, ale nie da się na te wątpliwości odpowiedzieć w sposób pewny.

Dopiero z okazji ostatniego remontu wszystkie zachowane wota można było poddać oględzinom, odczytując przy tym prawidłowo inskrypcje ${ }^{37}$. Okazuje się, że z cytowanego niegdyś przez Wandę Karkucińską dziewiętnastowiecznego spisu ocalały wszystkie srebrne blachy prócz wotum malarza Pawła Kulczyńskiego, które pochodziło z XVII stulecia ${ }^{38}$. Duża to szkoda, bowiem właśnie najstarsza, siedemnastowieczna grupa wotów jest najcenniejsza i szczególnie ciekawa jako dość spójny zespół. Tworzą ją (oprócz wspomnianego już wotum z 1650 roku) cztery pary srebrnych blach, na których ukazano członków trzech miejscowych rodów. Owe cztery pary wotów zostały najwyraźniej zaprogramowane wspólnie, to znaczy nie tylko wykonane jednocześnie i z jednej okazji, ale bodajże również przeznaczone do pospólnej ekspozycji. Otóż każda para blach nosi na sobie dwa wyobrażenia: Ukrzyżowanego i Matki Boskiej z orantami, jednakże zdaje się, że komplet stanowią dopiero blachy ofiarowane przez obie rodziny. Najważniejsze są owe dwie częściowo pozłacane blachy, na których widzimy członków dwu fundatorskich rodów i które tematycznie się uzupełniają.

Oto małżeństwo Mączków pod krucyfiksem i małżeństwo Łapichów z dziećmi u stóp Matki Bożej Różańcowej (il. 12a, 12b). Te wota niewątpliwie tworzą komplet. Powiększa go para kolejnych blach; są one skromniejsze, mniejsze i niepozłacane.

36 Op. cit., k. 18 recto, przeł. Jacek Kowalski.

37 Redagując zamieszczony w monografii artystycznej kolegiaty podrozdział dotyczący wotów (KowALSKi 2007, s. 231-240), musiałem z konieczności posługiwać się fotografiami wykonanymi na znacznej wysokości i to zza szyby, nie uzyskałem bowiem zgody na demontaż przytwierdzonych trwale gablot. Stąd liczne błędy i niekompletność ówczesnego omówienia.

38 Zob. KARKUCIŃSKA 2007, s. 106. 

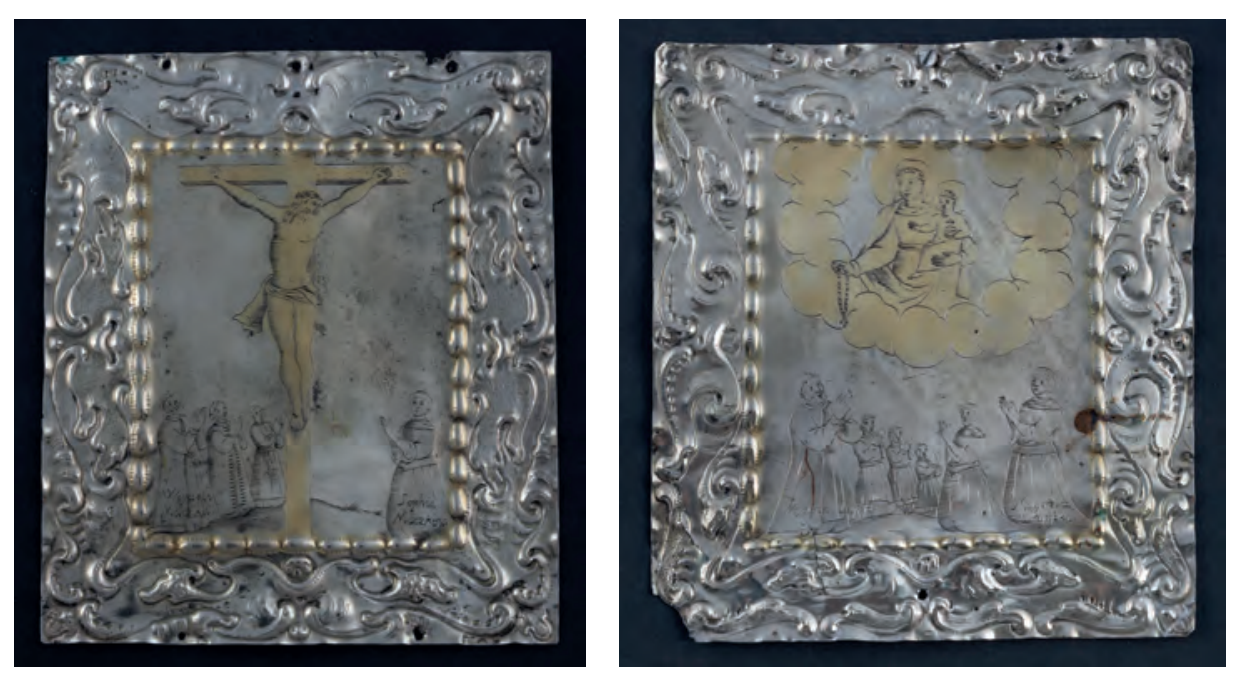

12. Wota Wojciecha i Zofii Mączków oraz Wojciecha i Małgorzaty Łapichów vel Lapiszów, fot. Piotr Łysakowski, 2018

$\mathrm{Na}$ jednej z nich widzimy grupę Ukrzyżowania z sygnaturą Wojciecha Łapicha, na drugiej - dwóch młodszych Mączków u stóp Matki Bożej (il. 13a, 13b) ${ }^{39}$. Do powyższych blach dołącza jeszcze para serc ufundowanych przez Łapicha, wykonanych jednak może z osobnego zamówienia ${ }^{40}$. Kolejny nieodległy czasowo zespół tworzy para blach fundacji gospodarzy Jana i Jagniszki Groszów z Pierzchna ${ }^{41}$, bogatej wsi, w której znajdował się filialny kościół parafii kórnickiej (il. 14a, 14b). Do Groszów dołączył pracowity (a zatem chłop) Grzegorz z Pierz[chna], który sprawił srebrne berło Matki Boskiej.

Postaci powyższych ofiarodawców są nam mniej więcej znane. Przedstawiciele rodu Groszów występują w spisie gospodarzy pierzchneńskich z połowy XVII wieku ${ }^{42}$. Przede wszystkim jednak w chwili zawiązania bractwa różańcowego w roku 1677 wójtem był niewątpliwie ten sam Wojciech Łapich (vel Lapisz), który widnieje na blasze, w tym samym zaś roku odnotowano również Wojciecha Mączkę jako wójta. Obaj byli prominentnymi członkami cechu szewców i obaj w latach 60., 70.

\footnotetext{
39 Jeśli nie jest to po prostu błąd w sztuce, być może artysta zadbał o to, aby zarówno w tej, jak i w poprzedniej parze blach Ukrzyżowany znalazł się po stronie ważniejszej heraldycznie - prawej, co spowodowało jednak, że Jego Matka stoi wyjątkowo niekanonicznie, po lewicy Syna, Chrystus skłania głowę ku Niej stojącej pod krzyżem, acz i ku Jej wyobrażeniu na drugiej blasze, z której Maria wyciąga swą dłoń także ku Niemu.

40 Serca te sygnowane są pismem innego rodzaju, z użyciem innej czcionki i innej grafii tego samego imienia i nazwiska: Wociech Lapisz.

${ }^{41}$ Wieś położona kilka kilometrów na północny wschód od Kórnika.

${ }^{42}$ W roku 1653 Wawrzyniec Grosz odnotowany został w gronie 10 gospodarzy z Pierzchna, zob. HŁYŃ/Potocka 2007, s. 323.
} 


\section{TECHNE \\ T E X N H \\ SERIA NOWA
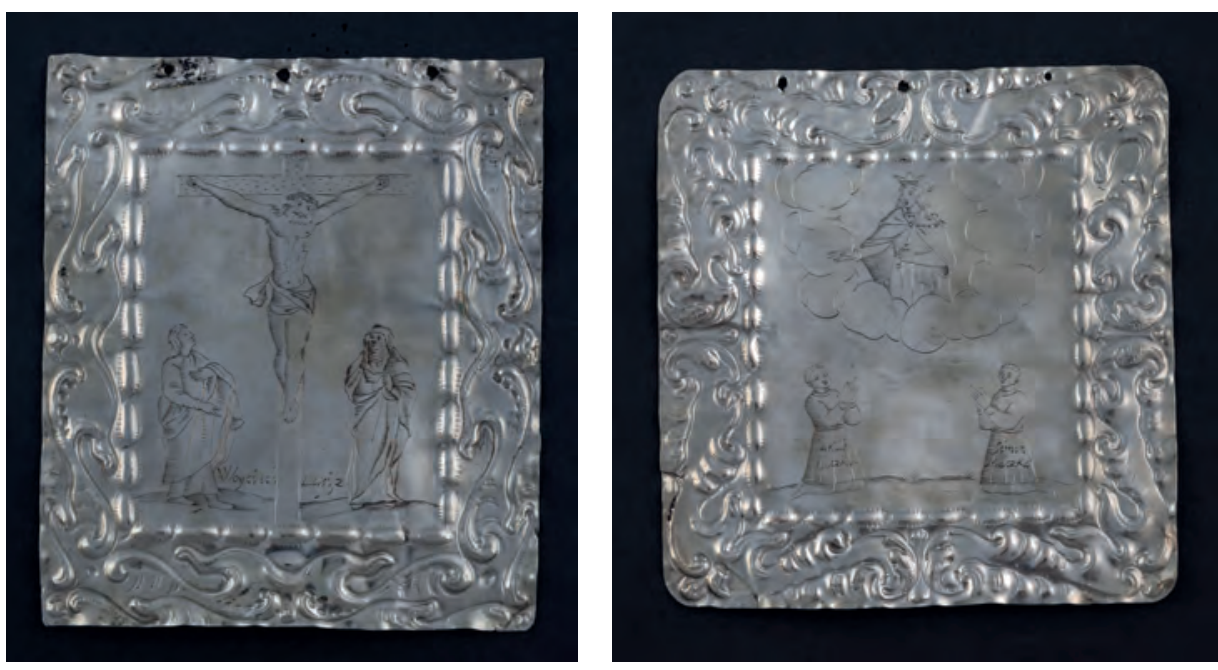

13. Wota Wojciecha Łapicha vel Lapisza oraz Jakuba i Szymona Mączków, fot. Piotr Łysakowski, 2018
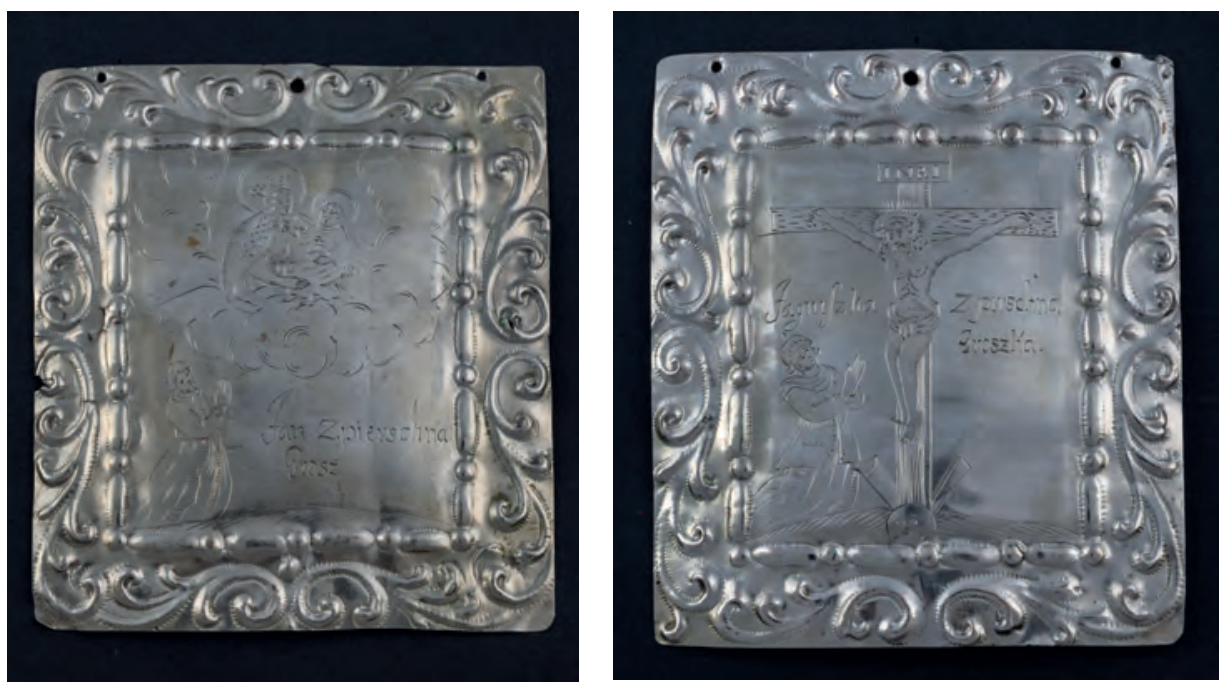

14. Wota Jana i Jagniszki Groszów z Pierzchna, fot. Piotr Łysakowski, 2018

i 80. XVII wieku kilkakrotnie sprawowali urzędy wójta i burmistrza ${ }^{43}$. Wojciech Łapich miał też ufundować w tym czasie kilka kielichów mszalnych, co odnotowała księga bracka ${ }^{44}$. Tak więc 10 omówionych powyżej srebrnych blach powstało w cza-

43 Eapicha odnotowano jako burmistrza w latach 1680-1682, 1685 i 1687, Wojciecha Mączkę zaś w latach 1661, 1666-1668 i 1670; jak już wiemy, w roku 1677 sprawował urząd wójta. Przypomnijmy, że kadencja burmistrza trwała wówczas rok, zob. NiEMIR 2007.

44 Tak podaje księga bracka, zob. MATUszek 1937, s. 22; NiEMIR 2007, s. 389. 

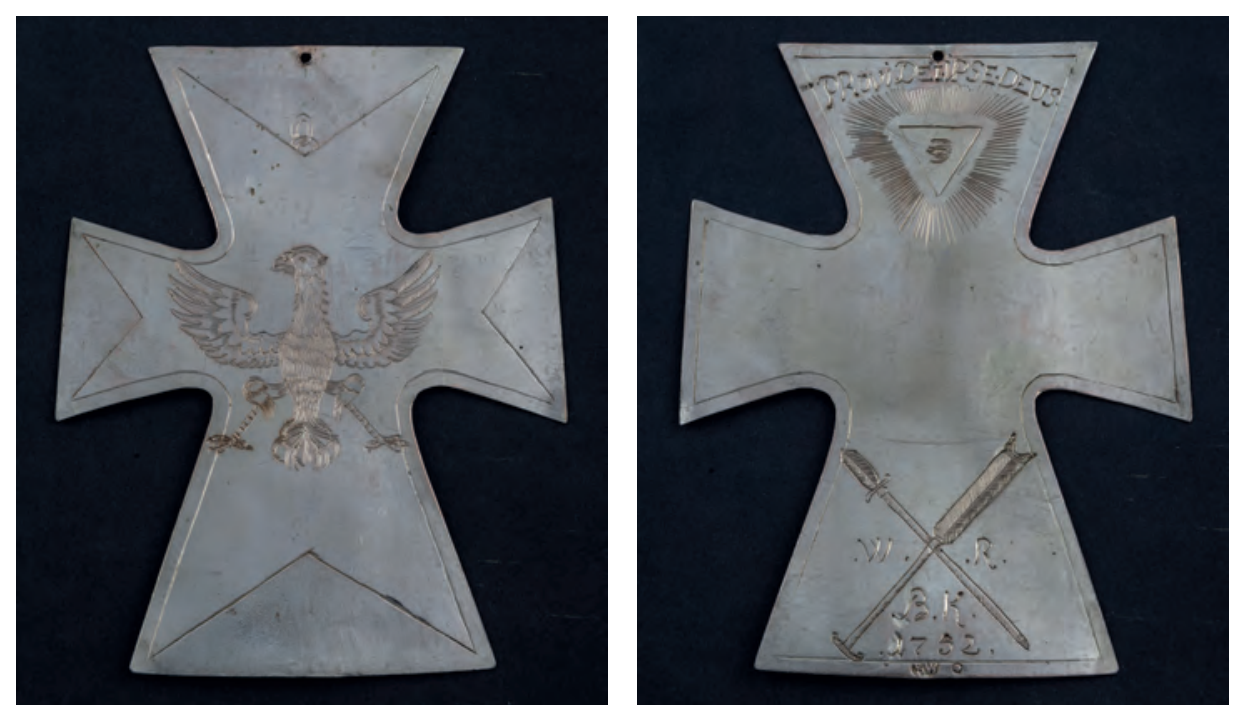

15. Duustronne wotum burmistrza Kórnika Wojciecha Robińskiego (?) z 1752 roku, fot. Piotr Łysakowski, 2018

sowej bliskości - w ostatniej ćwierci XVII wieku. W tymże czasie bracki ołtarz Matki Bożej z cudownym obrazem wciąż jeszcze stał przy filarze nawy południowej, naprzeciwko wejścia do wciąż jeszcze istniejącego protestanckiego mauzoleum.

Należałoby jednak zapytać, czy omówiony zespół blach można rzeczywiście nazwać wotami bądź ex-wotami? Otóż nie widzimy tu śladu jakiejkolwiek prośby czy dziękczynienia. Gesty wyobrażone na blachach wyrażają raczej akt pobożnego daru podjęty przez familie urzędującego wójta i burmistrza, a zatem w jakimś sensie nawet w imieniu całej miejscowej społeczności. Tego rodzaju fundacja miała miejsce zapewne z jakiejś szczególnej okazji - na przykład ufundowania ołtarza lub zawiązania bractwa różańcowego. Być może zainaugurowała ona pewną miejscową „burmistrzowską tradycję”. Tezę taką potwierdzałby szereg późniejszych wotów, na których udało się ostatnio rozpoznać inicjały odpowiadające konkretnym burmistrzom, co więcej, inicjałom towarzyszą daty roczne odpowiadające okresom burmistrzowskiego urzędowania. Oto zatem dwustronnie rytowany krzyż, nawiązujący formą do Orderu Orła Białego (il. 15a, 15b) ${ }^{45}$, z inskrypcją WRBK 1752, czyli zapewne Wojciech Robiński Burmistrz Kórnika 1752 - jest to właśnie rok, w którym Robiński pełnił urząd burmistrza ${ }^{46}$. A oto repusowana blacha w kształcie kartusza, zakupiona jako gotowy półprodukt, na której domorosły artysta wyrył datę 1754

45 Sygnował je nieznany dziś złotnik o inicjałach S.W. Wotum to nosi na jednej stronie wizerunek niekoronowanego orła, na drugiej Oko Opatrzności z napisem PROVI[dentia] DEI IPSE DEUS (Opatrzność Boża [jest] samym Bogiem). W tym miejscu dziękuję Michałowi Błaszczyńskiemu za zwrócenie mi uwagi na podobieństwo formy tego wotum do Orderu Orła Białego.

46 Zob. Niemir 2007, s. 390; KARKUCIŃSKA 2007, s. 140. 
i podpis: Mateus Swiontkofski (il. 16) - tenże był znany jako stołowy cechu szewskiego ${ }^{47}$ i burmistrz $\mathrm{w}$ tymże roku ${ }^{48}$. Poza innymi wotami ${ }^{49}$ uwagę zwraca blacha wyjątkowo prymitywna, z karykaturalnym wręcz wizerunkiem Matki Boskiej, pod którą klęczy jakby para małżonków. Nieortograficzny podpis z nieoczywistą, bodaj mylnie wpisaną datą 1704 (il. 17) s0 $^{50}$ dsyła do Kazimierza Więckowicza i Andrzeja Mielcarzowicza: pierwszy był burmistrzem sąsiedniego wobec Kórnika miasteczka Bnin w roku 1725, drugi - rok później. Jednak zapewne obaj, jak to się zwykle działo, mogli już sprawować ten urząd wcześniej i to kilkakrotnie. Czyżby więc był to dar włodarzy sąsiedniej miejscowości, która wprawdzie również posiadała murowaną, gotycką farę, ale bez cudownego obrazu - i może dlatego burmistrzowie Bnina postanowili afiszować się w niedalekim sanktuarium konkurencyjnego miasteczka, a może nawet czuli się zobowiązani do takiego gestu?

$\mathrm{W}$ dotychczasowych badaniach nad srebrnymi blachami wotywnymi z rzadka tylko ${ }^{51}$ i na marginesie poruszano kwestię tego rodzaju wotów-niewotów, które były świadectwem pobożności, nie wyrażając konkretnej prośby czy dziękczynienia. A przecież chodzi tu niejednokrotnie o najważniejsze zespoły srebrnych blach, dla których właściwe wota wydają się już tylko skromnym dodatkiem ${ }^{52}$.

Tylko niektóre przedmioty z tej „burmistrzowskiej” grupy nasuwają myśl o prośbie lub podziękowaniach, ale bez żadnej pewności. Na przykład gołębica Ducha Świętego ofiarowana przez Józefa Szelążkiewcza mogłaby wiązać się z narodzeniem jego dziecka, które dwa lata później, w roku 1754, zmarło jako infans duorum

\footnotetext{
47 KARKUCIŃSKA 2007, loc. cit.

48 Niemir 2007, loc. cit.

49 Z roku 1752 pochodzi opatrzona tą datą tabliczka z wizerunkiem gołębicy Ducha Świętego, podpisana Josef Sieląskiewic. Józef Szelążkiewicz występuje jako członek cechu szewców w 1747 roku, zob. KARKUCIŃSKA 2007, s. 140. Datę 1756 nosi para rokokowych kartuszy z wyobrażeniem Oka Opatrzności, Trójcy Świętej oraz inicjałami S.K. Inicjały te mogą sugerować, że wotum złożył Szymon Kopanka, członek cechu bednarzy, który w tym czasie posiadał dom w rynku, zob. KARKUCiŃSKA 2007, s. 133, 139. W roku kolejnym, 1757, ofiarodawca (czy może ofiarodawcy?) o inicjałach K.W.M.Z. zawiesił plakietę z repusowaną postacią Chrystusa Frasobliwego. Rok 1758 zaznaczył się repusowanym kartuszem z postacią św. Jana Nepomucena, którego ofiarodawcą był Józef Selzki.

50 Napis można odczytać: KAZIMIR WIENCHOWIC MIELCARZAMKOWI[C?].

51 Zob. np. KowALSKI 1994; JAGLA 2010.

52 W tym miejscu powtórnie wypada zwrócić uwagę na fakt, że istniejący dziś zespół wotów z XVII i XVIII wieku nie musi pochodzić wyłącznie z ołtarza obrazu Matki Bożej. Dziś bowiem pomiędzy wotami znalazły się pochodzące z XVII i XVIII wieku trzy korony i dwa komplety "promieni”, niewątpliwie identyczne z przedmiotami, które odnotowywano w spisach sreber kościelnych począwszy od 1806 roku, ale wówczas ozdabiały one obrazy św. Anny, św. Wawrzyńca, św. Rocha i św. Antoniego (Archiwum Parafii Kórnik, Akta Kościoła parafialnego tyczące się sreber..., k. 5). Niewykluczone, że niektóre z pozostałych wotów również mogły należeć do innych ołtarzy.
} 
$155 \mid \begin{gathered}\text { TECHNE } \\ \text { TEX N H } \\ \text { SERIA NOWA }\end{gathered}$
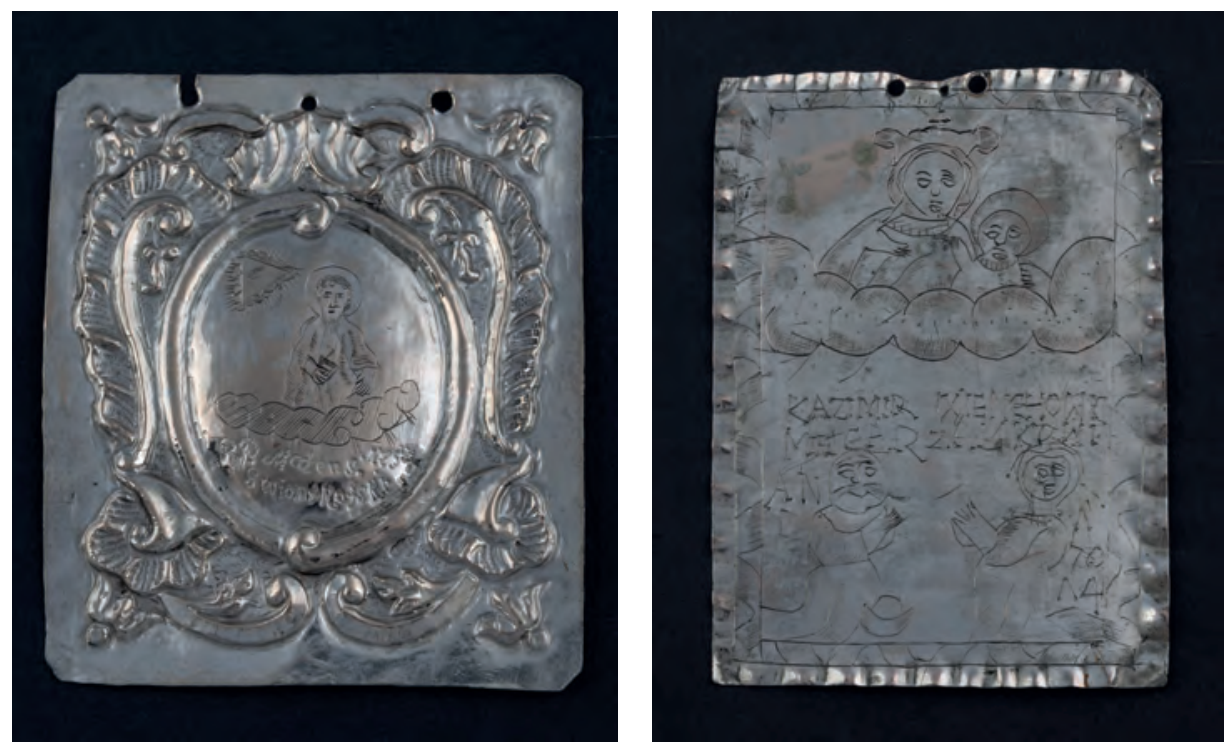

16. Wotum burmistrza Kórnika Mateusza Świątkowskiego z 1754 roku, fot. Piotr Łysakowski, 2018

17. Domniemane wotum burmistrzów Bnina, Kazimierza Więckowicza i Andrzeja Mielcarzowicza (1704?, 1724?), fot. Piotr Łysakowski, 2018
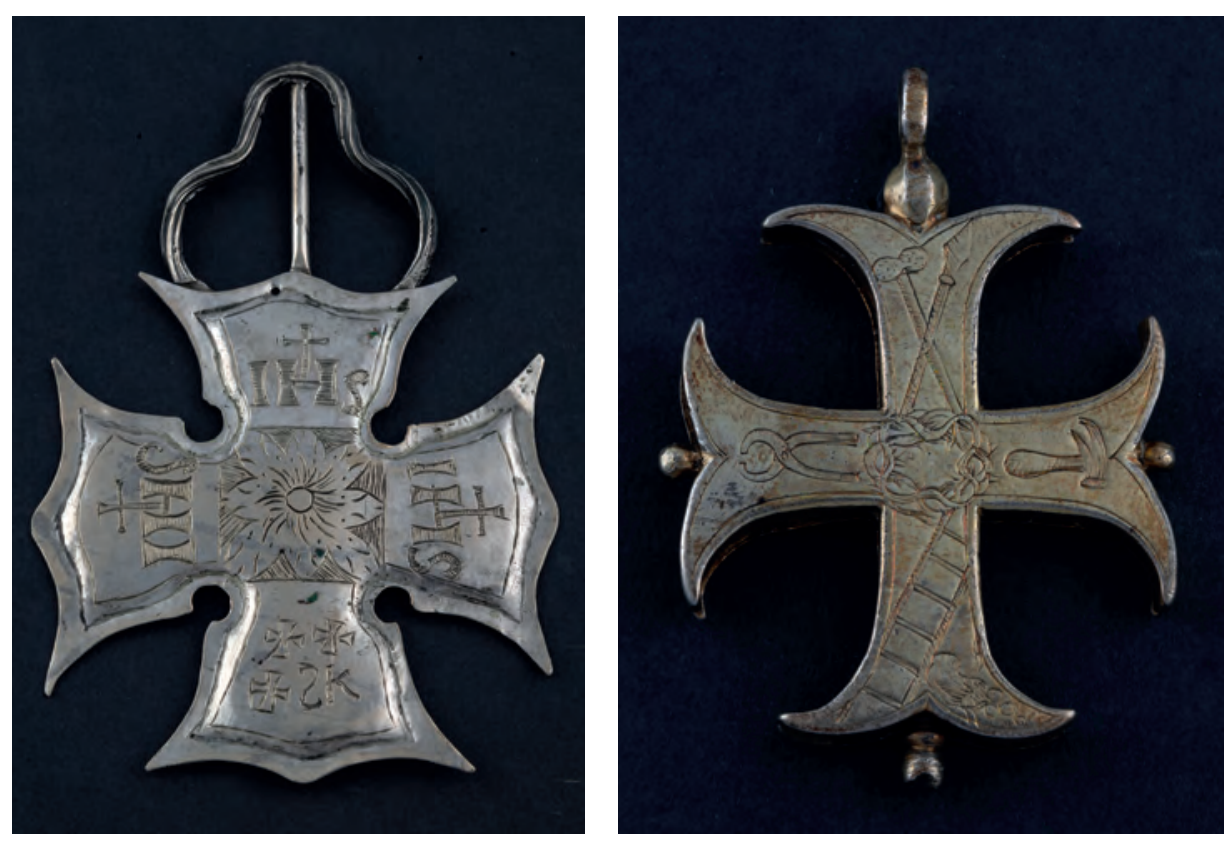

18. Wota w formie krzyży, XVII wiek (?), fot. Piotr Łysakowski, 2018 
annorum, potomek famatorum Szeląszkiewiczów. Pod inicjałami S.K. mogłaby się ukrywać - co jednak jest wielce wątpliwe - Sophia Korczyńska, zmarła 3 listopada tegoż roku w wieku 24 lat i pochowana na cmentarzu przy kolegiacie. Natomiast śladem próśb i podziękowań są wszystkie pozostałe nowożytne wota, wyraźnie błagalne bądź dziękczynne. Dziwna rzecz, że zachowały się one jakby „w wyborze”, po jednej sztuce z różnych rodzajów, których odpowiedniki znajdziemy w setkach dawnych sanktuariów sarmackiej Polski. Są to wyobrażenia ramienia, nogi, ludzkiego korpusu i pary bydła, związane niewątpliwie z prośbami o zdrowie własne i żywego inwentarza. Są też wota w postaci drogocennych przedmiotów: szlachetny kamień w oprawie (może dawna zapona srebrnej sukienki?), kilka sznurów korali, siedemnasto- lub osiemnastowieczny medal związany z którymś z rzymskich jubileuszy, przywołujący patronów czterech rzymskich „bazylik większych” (zapewne owoc nawiedzenia Stolicy Apostolskiej w Roku Jubileuszowym przez któregoś z wiernych) i dwa niewielkie, srebrne krzyże, bodaj również siedemnastowieczne (il. 18a, 18b). Jeden z nich powstał już jako wotum i nosi inicjały S.K. Drugi, wyjątkowo kunsztownie wykonany jako gruby, plastyczny „krzyż liliowy” o rozdwojonych końcach ramion i zaopatrzony w zawieszkę w postaci kółka, dekorowany jest obustronnie rytowanymi wyobrażeniami narzędzi Męki Pańskiej. Należał niewątpliwie do „nabożnej biżuterii” ofiarodawcy, który pierwotnie nosił go na łańcuszku, a potem ofiarował do Matki Bożej.

\section{Bibliografia}

BIeŚ/GrZebień 2016 - Andrzej P. Bieś SJ, Ludwik Grzebień SJ, Obrazy Matki Bożej Śnieżnej (Salus Populi Romani) w Polsce na przełomie XVI i XVII wieku, Kraków 2016.

Chrzanowski 1974 - Tadeusz Chrzanowski, Rzeźba lat 1560-1650 na Ślasku Opolskim, Warszawa 1974.

CichoŃsKa 2014 - Justyna Cichońska, Próba rekonstrukcji wygladu nagrobków Górków z kościoła pw. Wszystkich Świętych w Kórniku, Poznań 2014, maszynopis pracy magisterskiej napisanej pod kierunkiem Jana Skuratowicza w Bibliotece Instytutu Historii Sztuki UAM.

DĄBROWSKA 2019 - Urszula Dąbrowska, Badania wystroju wnętrz kościoła parafialnego pw. Wszystkich Świętych w Kórniku, 2019, maszynopis zdeponowany w APP.

DolCZewski 2000 - Spis złotników poznańskich od XV do XVIII wieku wg Tadeusza Nożýnskiego. Opracował Zygmunt Dolczewski, „Kronika Miasta Poznania” 2000, nr 1, (Złotnicy), s. 7-35.

DzıUBKowa 2004 - Szlachetne dziedzictwo czy przeklęty spadek. Tradycje sarmackie w sztuce i kulturze, red. Joanna Dziubkowa, Muzeum Narodowe w Poznaniu 2004.

ECKHARDTÓWNA 1935 - Joanna Eckhardtówna, Relief alabastrowy $z$ XVI wieku w kościele parafialnym w Kórniku, „Biuletyn Historii Sztuki i Kultury”, t. 3 (1934-1935), nr 4, s. 374-378. 
Harasimowicz 1986 - Jan Harasimowicz, Mauzoleum Górków w Kórniku, „Biuletyn Historii Sztuki”, t. 48 (1986), s. 277-298.

HŁYŃ/Potocka 2007 - Maria Hłyń, Ilona Potocka, Dzieje i stan współczesny wsi gminy kórnickiej, [w:] Z dziejów Kórnika i Bnina. Studia i materiały, red. Jerzy Fogel, t. 1, Poznań 2007, s. 301-335.

JAGLA 2010 - Jowita Jagla, Wieczna prośba i dziękczynienie. O symbolicznych relacjach między sacrum i profanum w przedstawieniach wotywnych z obszaru Polski Centralnej, Warszawa 2009.

JUREK 2018 - Tomasz Jurek, Biskupstwo poznańskie w wiekach średnich, Poznań 2018.

JURKOWlANIEC 2008 - Grażyna Jurkowlaniec, Epoka nowożytna wobec średniowiecza. Pamiątki przeszłości, cudowne wizerunki, dzieła sztuki, Wrocław 2008.

KARKUCIŃSKA 2007 - Wanda Karkucińska, W czasach staropolskich, cz. 2, [w:] Z dziejów Kórnika i Bnina. Studia i materiały, red. Jerzy Fogel, t. 1, Poznań 2007, s. 97-148.

KARPOWICZ 2010 - Mariusz Karpowicz, O niektórych figurach w polskich nagrobkach XVI-XVII wieku, „Biuletyn Historii Sztuki”, t. 72 (2010), s. 31-60.

KĄSINOWSKA 2019 - Róża Kąsinowska, Zamek w Kórniku, wyd. drugie poprawione i poszerzone, Polska Akademia Nauk Biblioteka Kórnicka, Kórnik 2019.

KęBŁOWSKi 1969 - Janusz Kębłowski, Sztuka renesansu i manieryzmu. Rzeźba, [w:] Dzieje Wielkopolski, t. 1: Do roku 1793, red. Jerzy Topolski, Poznań 1969, s. 638-664.

KorneCKi 1992 - Marian Kornecki, Matka Boska Polska. Adaptacja i rozpowszechnienie typu ikonograficznego obrazu Matki Boskiej Śnieżnej od XVI do XVII wieku, [w:] Dzieje Lubelszczyzny, t. 6: Między Wschodem a Zachodem, cz. 3: Kultura artystyczna, red. Tadeusz Chrzanowski, Lublin 1992, s. 365-398.

Kosman 1978 - Marceli Kosman, Opowieści Kórnickie, Poznań 1978 [nowe wydanie: Kórnik 2010].

Kościół 1841 - Kościół w Kurniku, [brak inf. o autorze], „Przyjaciel Ludu”, R. 8 (1841), nr 12, s. 89-90.

KowALSKI 2005 - Jacek Kowalski, Neogotycka przebudowa kolegiaty kórnickiej, „Pamiętnik Biblioteki Kórnickiej”, t. 27 (2005), s. 239-288.

KowAlski 2007 - Jacek Kowalski, Kolegiata kórnicka. Od prywatnej świątyni do romantycznego sejmu Rzeczypospolitej. Monografia artystyczna, Kórnik 2007.

KOWALSKi 1994 - Piotr Kowalski, Prośba do Pana Boga. Rzecz o gestach wotywnych, Wrocław 1994.

KrYGIER 1998 - Marek Krygier, Alabastrowa Pasja z kościoła pw. Wszystkich Świętych w Kórniku, Poznań 1998, maszynopis, egzemplarze dostępne w zbiorach Parafii Kórnik i Wojewódzkiego Oddziału Służby Ochrony Zabytków w Poznaniu.

KRYGIER 1999 - Marek Krygier, Ołtarz w kaplicy Matki Boskiej Różańcowej w kościele parafialnym pod wezwaniem Wszystkich Świętych w Kórniku. Skrócony opis prac konserwatorskich, Poznań 1999, maszynopis, egzemplarze dostępne w zbiorach Parafii Kórnik i Wojewódzkiego Oddziału Służby Ochrony Zabytków w Poznaniu.

KRYGIER 2005 - Marek Krygier, Konserwacja reliefu alabastrowego „Alegoria Odkupienia” $z$ kościoła p.w. Wszystkich Świętych w Kórniku, Kobylnica grudzień 2005, maszynopis, egzemplarze dostępne w Archiwum Parafii Kórnickiej i Wojewódzkiego Oddziału Służby Ochrony Zabytków w Poznaniu.

KZSP 1961 - Katalog Zabytków Sztuki w Polsce, t. 5: Województwo poznańskie, red. Teresa Ruszczyńska, Aniela Sławska, z. 25: Powiat śremski, oprac. Zofia Białłowicz-Krygierowa, Warszawa 1961.

KZSP 2002 - Katalog Zabytków Sztuki w Polsce. Seria nowa, t. 7: Miasto Poznań, red. Eugeniusz Linette, Zofia Kurzawa, Andrzej Kusztelski, cz. 2: Śródmieście. Kościoły i klasztory, oprac. zbiorowe, z. 2, Warszawa 2002.

LIPIŃSKA 2001 - Aleksandra Lipińska, Mecheleńskie reliefy alabastrowe w Polsce, „Rocznik Historii Sztuki”, t. 63 (2001), s. 183-221. 
ŁUKASZEWICZ 1858-1863 - Józef Łukaszewicz, Krótki opis historyczny kościołów parochialnych, kościółków, kaplic, klasztorów, szkółek parochialnych, szpitali i innych zakładów dobroczynnych w dawnej dyecezyi poznańskiej, t. 1-3, Poznań 1858-1863.

Niemir 2007 - Jacek Niemir, Spisy burmistrzów i proboszczów Kórnika i Bnina, [w:] Z dziejów Kórnika i Bnina. Studia i materiały, red. Jerzy Fogel, t. 1, Poznań 2007, s. 389-392.

NOWACKI 1964 - Józef Nowacki, Archidiecezja poznańska w jej granicach historycznych i jej ustrój, t. 2: Dzieje archidiecezji poznańskiej, Poznań 1964.

SkURATOWICZ 1976 - Jan Skuratowicz, Z badań nad rzeźbą nagrobna w Polsce. Nagrobki Czarnkowskich w Czarnkowie i Górków w Kórniku, [w:] Renesans. Sztuka i ideologia, Warszawa 1976, s. 476-486.

SoćKo 2012 - Adam Soćko, Piaentinus, Canavesi i Horst. Kilka uwag na marginesie rozważań Mariusza Karpowicza o nagrobkach renesansowych w Polsce, „Biuletyn Historii Sztuki”, t. 74 (2012), s. 343-352.

WARDZYŃSKI 2008 - Michał Wardzyński, Marmury i wapienie południowoniderlandzkie na ziemiach polskich od średniowiecza po 2. poł. XVIII w. Import i zastosowanie w małej architekturze i rzeźbie kamiennej, „Biuletyn Historii Sztuki”, t. 70 (2008), nr 3-4, s. 307-357.

WIESIOŁOWSKI 1997 - Jacek Wiesiołowski, Mikołaj Krystynowicz z Lublina, polski kurialista z drugiej połowy XV wieku, „Roczniki Historyczne”, t. 63 (1997), s. 79-94. 


\section{From the heretic mausoleum to the catholic sanctuary New research on the chapel of Mary, mother of Jesus at Kórnik Collegiate Church}

$\mathrm{T}$ he parish in Kórnik was established in 1437 thanks to the founders and owners of the town, the Górka family. Probably at the same time the parish church, then still under construction, was consecrated and the bishop of Poznań, Uriel Górka, established a college of canons in 1495. In the mid-sixteenth century, the Górkas converted to Protestantism and gave the church to dissenters. As they then lost their right to burial in the ancestral chapel at the Poznan cathedral, the last member of the family, Stanisław Górka, built a mausoleum in the form of a domed chapel at the parish collegiate church, where his brothers Łukasz and Andrzej, and ultimately also Stanisław himself, were buried $(+1592)$. The architectural structure of the mausoleum is still legible, despite the subsequent liquidation of the dome and changes in the shape of the window openings.

In 1584, Stanisław made an agreement with Henryk Horst, a Lviv sculptorfrom the Netherlands, to make three tombstones. The differences in the form of the preserved figures do not allow us to determine whether Horst fulfilled his obligation by carrying out these works with the help of his associates, or whether he made only one tombstone, and the other two come from the beginning of the $17^{\text {th }}$ century, when the chapel was completed by his Catholic nephew Jan Czarnkowski - the foundation plaque bares date 1603. The researchers' opinions as to the authorship of the statues are divided. Czarnkowski gave the church back to his fellow believers.

The tombstones have not been preserved in their entirety. The alabaster and marble figures of the dead, the alabaster bas-relief of the Allegoric Crucifixion and the crucifix and several other fragments that are located in various places of the church. Some of them were made of alabaster from a quarry near Lviv, some of alabaster from the Netherlands. The allegorical crucifixion is entirely a Dutch import. A large number of sandstone and alabaster details, probably from the architectural frames of the tombstones, is kept in the basement of the Kórnik Castle (today the Kórnik Library of the Polish Academy of Sciences).

After the church was regained by Catholics, they set up the sanctuary of the miraculous image of Mary in the type of Our Lady of the Snow. Initially, the painting was located in the altar next to the pillar adjacent to the entrance to the chapel. In 1677 a rosary brotherhood was established with him. The cult of the miraculous image of the Mother of God is evidenced by the sources and a group of magnificent silver votive offerings and ex-votives from the $17^{\text {th }}$ and $18^{\text {th }}$ centuries, the oldest of which, given by 


\section{TECHNE \\ \begin{tabular}{l|l} 
T E X N H & 160
\end{tabular} \\ SERIA NOWA}

nobility, is dated 1650. The younger votive offerings and ex-votive offerings come from the last quarter of the $17^{\text {th }}$ century and later centuries. The $17^{\text {th }}$ and $18^{\text {th }}$ century votive offerings are signed with the names of several mayors of Kórnik and the neighboring Bnin, as well as local craftsmen and peasants from the neighboring village of Pierzchno, in which there was a branch church. It was possible toidentify a few contractors, who were goldsmiths active in the $18^{\text {th }}$ century in Poznan.

In the years 1735-1737, the then owner of the Kórnik estate, Teofila Szołdrska-Potulicka née Działyńska, carried out a major renovation of the church and the chapel, which was now designated as a center of Marian cult. Two of the tombstones were moved to the chancel, and a sail vault was built instead of the dome. In 1739, an altar was installed, which incorporatedthe miraculous painting, accompanied by a seventeenth-century painting of St. Lawrence in the second storey of the retable. However, the present altar setting with the oil-painted curtain of the main painting, showing the handing over of the Holy Rosary by Mary to Saint Dominik, comes from 1777-1783. It was made by the Poznań sculptor Augustyn Szeps (Schoeps) and the local carpenter Fryderyk Dera, and it was founded by the court tailor Józef Pudelewicz and the writer of the Kórnik estates, Józef Matelski, who belonged to the local burgher families.

After Teofila's death, in the last years of the $18^{\text {th }}$ century, her son commissioned the construction of a new sacristy with a founder's box. At that time, the entire complex of the chapel, sacristy and lodge was combined into one block with a common facade, which hides its internal heterogeneity. Apart from minor changes made in the nineteenth century, the present shape of the chapel and its furnishings reflect the conditionsin the second half of the eighteenth century.

From the end of the $18^{\text {th }}$ century, the chapel became a necropolis for the next owners of Kórnik.

Keywords: Stanisław Górka, Augustyn Szeps, Teofila Szołdrska-Potulicka née Działyńska, dome chapel, Henryk Horst, renaissance tombstones, Image of Our Lady of the Snow, votive offerings, ex-votive offerings 